\title{
The Revision and Codification of California Statutes 1849-1953
}

\author{
Ralph N. Kleps*
}

A

EARLY ATTEMPTS AT ORGANIZING THE STATUTE IAW

(1850-1870)

At its earliest session the California Legislature was compelled to choose between a codified form of the civil law on the one hand and the English common law system on the other. The chaotic condition of the law under which all government operated immediately prior to the 1848 Treaty of Guadalupe Hidalgo has been described by early writers. ${ }^{1}$ Some of the uncertainties were resolved by the adoption of the Constitution of California on November 13,1849. The first legislature, meeting at San Jose on December 15, 1849, however, was confronted with the problem of creating the statutory foundation for a complete system of law in advance of California's admission to the Union in 1850 . Governor Peter H. Burnett recommended in his message to the legislature that it adopt the English law of crimes, law of evidence and law merchant, and that the Louisiana Civil Code and Code of Civil Procedure be enacted. ${ }^{2}$ A committee of the legislature appointed to study the matter reported back with a stirring defense of the common law system and expressed its view that the legislature could not hope, in the time available, to enact a codified system of law based upon the several sources suggested. This view prevailed and led to a repeal of substantially all laws in force other than those adopted at the 1849-50 session and to the adoption of the common law of England where no other provision was made. ${ }^{3}$ While this decision avoided the necessity for the legislature's attempting to enact a complete code of laws, that first session did enact detailed statutes governing crimes, criminal procedure, civil and probate procedure and corporations, with the result that substantial portions of the law were in effect codified for the time being. ${ }^{4}$ The first legis-

* Legislative Counsel, State of California ; Member, California Bar.

1 See Justice Nathanial Bennett's summary in 1 California Reports, Appendix 574-582; Van Alstyne, The California Civil Code, West's Anv. Crv. Cone 1-43 (1954).

2 Journats of Sentate and Assemaly 33 (1849-1850); Struck, History of Bencer and Bar of CaLIFornia 47 (1901).

31 California Reports, Appendix 588-604; Journats of Senate and Assearbly 323, 1125, 1204 (1849-1850). Cal. Stats. 1850, cs. 95 (now CaL. Crv. Code § 22.2) and 125.

4 Cal. Stats. 1850, cs. 99 (crimes), 119 (criminal procedure), 142 (civil procedure), 129 probate procedure) and 128 (corporations). These acts were divided into parts, titles and chapters and consisted of hundreds of sections. The statute on criminal procedure, for example, contained 746 sections. The 1850 statutes on civil and criminal procedure were based almost entirely on the 1848-1849 Fiem Codes of Cturl Procedure and Crmitnal Procedure drafted in New York. See Parma, The History of the Adoption of the California Codes, 22 Law Lib. J. 8, 12 (1929); Reppy, Daym Dudley Ftetd Centexary Essays 34, 45 (1949). 
lature was understandably concerned about the availability of its acts and provided for speedy publication of the statutes, particularly those of general application. ${ }^{5}$

Sessions of the legislature were annual from 1850 to 1863 , and the need for some revision of the statutes was apparent when the second annual session of the legislature met in January, 1851. Stephen J. Field, who was an assemblyman at that second session, has been given credit for the statutes passed at that time which were based upon David Dudley Field's work in New York and which revised the civil and criminal practice acts. In addition, the acts regulating probate procedure and the organization of the courts were revised. ${ }^{6}$ These revisions were accomplished as present day code revisions are accomplished in Califorma, by the express repeal of the earlier statutes and the substitution of the new and revised acts. Despite these substantial revisions in 1851 and the fact that only two sessions of the legislature had been held, both the outgoing Governor and the incoming Governor found occasion to suggest to the 1852 session the need for "an entire revision of our code of laws."7 Apparently as a result of this recommendation of both Governors, and the Attorney General as well, a bill was then introduced, calling for the appointment of a commission to codify the laws of the state. ${ }^{8}$ The bill was unsuccessful but the problems which gave rise to these expressions of concern grew worse with each session of the legislature thereafter and the records of those years reflect this. In 1853 the legislature passed a statute providing for a private compilation of the laws of the state, and the work, entitled "Compiled Laws of the State of California," was available by the time the next session met. It was apparently unacceptable in some measure, however, and an attempt to provide for an 1854 supplement failed in the legislature. ${ }^{9}$

Cal. Stats. 1850 , c.124.

6 Struck, History of Bench and Bar of Caxifornia 424 (1901). Cal. Stats. 1851, cs.1 (organization of courts), 5 (civil procedure), 29 (criminal procedure) and 124 (probate procedure).

7 Lt. Gov. John McDougal (who succeeded to the governorship upon the resignation of Peter Burnett on January 8, 1851) stated: "The present system is so cumbrous and unwieldy that only with difficulty can it be interpreted even by those having the law to administer; and in a less degree, certainly, by the great body of the people for whose benefit all laws should be enacted. In view, therefore, of the difficulties heretofore existing, in the formation of a proper judicial system, I would respectfully recommend the adoption of the suggestion made by the Attorney General, that a commission for the entire revision of our code of laws, be authorized." Incoming Governor John Bigler referred to the same problem. See SEN. Jour. 16,28 (1852).

${ }^{8}$ SEN. Jour. 91 (1852). See also AsSEMr. Jour. 42 (1853) for a similar reference.

0 Cal. Stats. 1853, c.79. This statute resulted from a resolution asking for a committee to study codification of the laws, AssEm. Jour. 165, 261 (1853), but while it calls for one Frederick $\mathrm{A}$. Snyder to "compile, codify and publish the laws of California," it is clear that an editorial compilation was desired. The legislature appropriated $\$ 10,000$, in return for which Snyder was to debver 1200 copies of a one-volume work. Some difficulties with the work arose from 
A proposal for the complete revision and codification of the laws of the state was made at the 1856 session but it was unsuccessful, and in both that session and the preceding one fruitless attempts were made to secure another authorization for compilation of the statutes. ${ }^{10}$ Commencing in 1857 and continuing for several years thereafter, "Wood's Digest of the Laws of California" served as the official compilation of the statutes of the state. Though called a "digest," this work was a standard, one-volume compilation of all of the general laws of the state, arranged alphabetically under subject matter headings. It was prepared by a deputy in the Secretary of State's office "in the intervals from official duty" over a period fron 1853 to 1857 . It had been presented to a committee of the legislature in 1856 which was favorably impressed, and the 1857 legislature gave it official sanction. ${ }^{11}$ By 1860 , however, the condition of the statute law had deteriorated sufficiently to cause Attorney General Thomas $\mathrm{H}$. Williams to recommend the appointment of a commission to codify the laws of the state, but two bills imtroduced to accomplish this were unsuccessful. This recommendation was repeated by Attorney General Williams in 1861 and 1862, together with an endorsement by Governor John G. Downey, but with the same result. ${ }^{12}$ In the session of 1863 and in the first biennial session of

the fact that the books were published in Boston and the 1854 legislature found it necessary to appoint committees to determine its status, Assem. Jour. 98, 127, 137, 178 (1854). The legislature refused to authorize a supplement but an appropriation was made to complete the payment to Snyder. (Cal. Stats. 1854, c.10, p.23).

10 In the 1855 session a Senate resolution was passed to study the cost of a compilation and publication of the laws by Deputy Secretary of State Wm. H. R. Wood, SEN. Jour. 684, 698 (1855).

In the 1856 session the unsuccessful bill to provide for revision and codification (1856 Session, A.B.15; Assem. Jour. 160 (1856)) named Stephen J. Field, Joseph G. Baldwin and Joseph Hoge as commissioners for that purpose.

11 Cal. Stats. 1857 , c.186, appropriated $\$ 5,000$ for 500 copies of a compilation of Wood's work, provided the statutes passed in 1857 were properly inserted and the superseded matter removed. The compilation was made "evidence of the law in all the courts of justice in the state" when certified by the Secretary of State and was to be completed within six months after the legislature's adjournment.

Dr. Wm. H. R. Wood was the "acting Secretary of State" during a controversy with Governor Bigler over custody of the Great Seal of California in 1855. See Dr. J. N. Bowman's account in CALIFORNIA BLUE BOoK 169 (1950). Dr. Bowman has also concluded that Wood was the author of the famous entry in the Secretary of State's Day Book for July 4 and 5, 1852, which is "engaged in celebrating the day, got drunk," and for the next day, "same, same." Wood died in 1864 and the fifth edition of his work in 1861 was apparently the last. In 1858 and 1860 there are references to the use of bis compilation as the official publication of the statutes. See SEN. Jour. 38 (1858); Cal. Stats. 1858, Res. c.28, p.360, using Wood's DrGest as the basis for publishing statutes in Spanish; Assear. Jour. 320 (1860) (A.B.172), bill purporting to amend a section of Woon's Digest.

12 Appendix to Journats of tHe Senate No. 5, p.6 (1860). Attorney General Thomas H. Williams stated:

"The propriety of appointing a commission of persons, learned in the law, to prepare a code of laws for this State is beginning to be discussed. 
1863-64, Governor Leland Stanford made a strong plea for legislation to provide for the revision and codification of the statute law of the state. ${ }^{13}$ The first message characterized our statutes as having fallen into a "state of wild confusion" and the latter message contained the following:

I would again, as I have once before, urge upon your attention the absolute necessity of a thorough revision and codification of the laws of California.

Citizens not versed by constant familiarity with their contents, and desirous of investigating the laws, stand aghast as they survey the fourteen ponderous tomes that constitute the statutes of this youthful state, and young aspirants to professional fame tremble as they cross the threshold that leads into this intricate abyss.

An act authorizing the appointment of a Commission to attend to this important duty would be hailed with satisfaction by the professional students of California law, and by all others who may have occasion to investigate the statutes.

In both sessions, however, the legislation offered to carry out the Governor's recommendation was defeated. Another approach to the problem of revising the statutes of the state is indicated by Statutes of 1861, Chapter 200, which required the clerks of the several courts of the state to make full and complete reports to the Governor each year concerning "any and all mistakes, errors, ainbiguities, conflicts, or cases of imperfect operation of the laws of this state."14

Commencing in 1865 a more complacent climate of opimon prevailed with respect to the codification of our statute law. The then Attorney General, John G. McCullough, reported that the compiled statutes of the state had been published during the year by Theodore $H$. Hittell, and that the appointment of a commission to revise and codify the statutes was not

"I am inclined to the opinion that wisdom dictates such action. I think it the only mode of approaching the greatest perfection in a system of laws of which the human mind is capable.

"Should you think it proper to direct the attention of the Legislature to this subject, and should they receive it favorably, then I suggest the proper course would be to appoint a commission and require them to report the result of their labors to the succeeding Legislature.

"After pursuing this course the duties of the incoming Legislature would be so abridged that, upon the passage of a few general laws now urgently required, they might fix an early day for adjournment, and thus save a large sum of money to the public treasury." See also Assear. JouR. 94 (1861); APPENDIX to ASSEMBIX JoURNALS (1861) No. 5, p.4; and AsSEMr. Jour 41 (1862); Appendix to the Journals of SeNATE AND Assearbix, Pt. I, No. 9, p.7 (1862).

13 For Stanford's 1863 message, see Parma, History of the Adoption of the Codes of California, 22 LAw LIB. J. 8-21 (1929); ASSEM. Jour. 52 (1863). Also ASSEM. Jour. 52 (1864).

14 This 1861 penal statute could conceivably still be in effect since it has never been expressly repealed. See STATutEs Continued IN ForCE $\$ 1648$, p.1010 (1873). However, the 1893 indexers concluded that it was superseded and pointed out that this statute was included in the unsuccessful Senate Bill 519 of the 1871-1872 session as one which the 1870-1872 Code Commissioners intended to repeal expressly. See INDEX TO LAW OF CAIIFORNIA 696 (1894); and INDEX to THE Laws of CALIFORNIA 78 (1921). See also, Report on Legislation Necessary to Maintain the Codes, LEGISLATIVE CounseI 25 (March 1, 1954) recommending its repeal. 
desirable. ${ }^{15}$ This comment was repeated in 1867 by the Attorney General, but incoming Governor Henry $H$. Haight mentioned the need for revision and codification in his inaugural message. ${ }^{16}$ Thereafter two measures were introduced, one of which became Chapter 365 of the Statutes of 1867-68. It created the first California "commission to revise and compile the laws of the state into a comprehensive and concise system." The members of the 1868 Commission were named in the statute and consisted of John Currey (Chief Justice of the California Supreme Court from 1866 to January 1, 1868), John B. Harmon and Henry Barber. Justice Currey apparently did not participate fully in the work of the commission, but the other two members filed a report at the $1869-70$ session of the legislature. ${ }^{17}$

The statute under which the 1868 Commission operated contemplated a complete revision and compilation of the laws of the state. It gave the commissioners broad discretion in the omission of laws "which in their judgment could be dispensed with without prejudice to the interests of the state," and it required the work to be completed by July 1,1869 , which was five months in advance of the next meeting of the legislature. The commissioners' report discloses the impossibility of performing the task assigned within the time allowed. ${ }^{18}$ They adopted an alphabetical arrangement of subjects, and noted their great difficulty in dealing with the numerous special and local acts relating to the counties throughout the state. The 1868 Commission mcluded several major policy recommendations in the report, among which were: (1) the passage of a law "providing for the codification, or the reduction 'into a written and systematic code for the whole body of

15 See 1 Appendix to Journal of Senate and Assemably No. 5, p.11 (1865-66). Governor F. F. Low concurred with the Attorney General and the codification bills which were introduced at that session were defeated, Assear. Jour. 55 (1865-66).

Fittels's Generax Laws of California $1186 \mathrm{pp}$. (1865) was supplemented in 1871 by Charles H. Parker of San Francisco. Hittell's two volume work apparently was published in four editions: 1865, 1868, 1870 and 1872.

16 See Assem. Jour. 102 (1867-68) for Governor Haight's message and 1 Appendix to Journats of Senate and Assearbly No. 7, p.6 (1867-68) for the Attorney-General's comment.

${ }^{17}$ A letter from Governor Haight to Justice Currey, dated January 13, 1870, discloses that the judge had attempted to resign as early as January 21,1869 . The Governor refused to accept the 1869 resignation because 10 months had passed since the judge's appointment. The statute only permitted $\$ 3,000$ to be paid each member as salary (at $\$ 400$ per month) until the work was complete, and the Governor felt that be could not find anyone to replace Justice Currey at such a late date. See 1020 State Arcurves, LetTers of THE Governors 532.

${ }^{18}$ The 1868 Commission's six page report is printed in 3 APPENDIX to Journats of SENATE AND Assensery No. 44 (1869-70). It indicates that the commissioners worked from April, 1868, to the convening of the 1869-70 session in December, 1869, and reports the "utter impossibility" of completing the work within tbe time allowed. The commissioners proposed several amendments to the Constitution as well as "revised statutes" dealing with some 30 topics covered by statute law. Their report lists some 90 alphabetical topics, but they are in detail only from $A$ to $L$ and the Codified Laws presented to the legislature in 1870 are detailed only from $A$ to $C$. 
the law of this state,' as has already been done in the State of New York, by the creation of a civil, a political and a criminal code"; (2) a standard set of statutes for county government, together with the elimination of special and local legislation from the revised statutes; and (3) the passage of an act permitting the commission to finish its work "carefully and properly." 10 The inability of the 1868 Commission to complete its work was noted both by Attorney General Jo Hamilton and by Governor Haight, and both requested the passage of legislation to compensate the commissioners despite their failure to complete the work, together with additional legislation to permit its completion. ${ }^{20} \mathrm{~A}$ number of bills were introduced dealing with the problem of statutory revision, but the one which became law created an entirely new commission and turned over to it all of the files and documents of the 1868 Commission. ${ }^{21}$

With the failure of the 1868 Commission and the determination of the legislature in 1870 to create an entirely new agency to carry on the work, the first twenty years of California statute-making came to a close. During that period, as is indicated by the material here summarized in some detail, there was a continuous and mounting dissatisfaction with the condition of our statute law. All attempts to deal with the problem were experimental, however, and no continuity was achieved. At the end of the period those required to use the statutes of California were compelled to make their way among the eighteen volumes of session laws or to rely upon Hittell's General Laws (through the 1863-64 session), together with the succeeding three volumes of session laws. It should be noted, however, that no statute was passed giving Hittell's work the benefit of a presumption or other official sanction, and the session laws remained the only official text. Perhaps the most interesting discovery with respect to these twenty years lies in the fact that there was so much agitation and discontent. This truth furnishes a much clearer background for the adoption of our 1872 codes, and indicates

10 The 1868 Commission commented (APPENDIX, supra note 18 at 6): "Your honorable body [the legislature] may rest assured that the revision, arrangement and correction of the mass of legislative Acts comprised in the statutes of this state, is neither a hight undertaking nor one to be properly accomplished in a hurry."

20 Report of Attorney General, 1 Appendix to Journats of Senate and Assembly No. 6, p.5 (1869-70); GoverNor's MEsSAGE, SEN. Jour. 54 (1869-70).

Resolutions were introduced inquiring as to the cause for the commissioners' failure to complete the task. See Assem. Jour. 157, 178, 892 (1869-70); 3 APPENDIX to JournaLs of Senate and Assemibly No. 36 (1869-70). The legislature, however, did appropriate funds to compensate Commissioner Henry P. Barber for his services "froun the time of the last payment to him" until July 1, 1869 (Cal. Stats. 1869-70, c.327). Quaere: was the work performed solely that of Barber?

21 The bill creating the 1870-72 Commission was $1869-70$ Session, A.B. 512 by T. A. Slicer of Nevada County, and it became Chapter 516 of the Statutes of 1869-70. The Governor signed the bill on the last day of the session; see Assear. Jour. 944 (1869-70). 
that the same ferment which existed elsewhere in respect to "codification of the laws" was in vigorous operation in early California."

B

THE 1870-74 CODE COMMISSION ${ }^{23}$

Many interesting questions are suggested by the legislature's 1870 decision to create an entirely new commission. From what has been noted, it is clear that there was dissatisfaction with the 1868 Commission's work. ${ }^{24}$ The terms of the statute under which the new commission was to operate are worth examination, particularly in light of the fact that the $1868 \mathrm{Com}$ mission committed itself to a codification of all of the laws of California on the lines of the New York precedent. ${ }^{25}$ With this background in mind the legislature said that the 1870-72 Commission should do the following: ${ }^{20}$

Upon the organization thereof, such Commission shall proceed to revise all the statutes of this State, including those enacted at the present session of the Legislature, and correct verbal errors and omissions, and suggest such improveinents as will introduce precision and clearness into the wording of the statutes, and by a supplemental report thereto to designate the Acts or parts of Acts which, in the opinion of the Commission, should be repealed, and prepare substitutes therefor when necessary; to

22 Reference has already been made to the argument over codification in the first session of the legislature. See note 3 supra. The world-wide aspect of the movement for codification is described in Reppy, David Dudley Fuend Centenary Essays (1949); also see Harrison, The First Half-Century of the California Civil Code, 10 CAIn. L. Rev. 185 (1922).

23 The 1870-74 Commission is customarily called the "Code Commission," but the statute creating it refers to a commission "for the purpose of revising and compiling the laws of this state" (Cal. Stats. 1869-70, c.516 $\$ 1$ ). The commissioners appear to have referred to themselves as a "Revision Commission" until after the adoption of the 1872 codes. Thereafter, their reports carry the "Code Commission" title. See ReporT of CODE CoManrssioners, 6 APPENDIX to JoURnars of Senate and Assensbly Nos.7 and 8 (1873-74).

24 Governor Haight's refusal to accept Justice Currey's resignation at a time when no further funds could be paid him, and the legislature's appropriation of money in 1870 for Commissioner Barber alone is an indication that perbaps some members of the commission were lacking in diligence. See notes 17 and 20 supra. Compare the detailed provisions in the 1870 statute designed to insure a "working" commission, Cal. Stats. 1869-70, c.516, §§ 4, 7, 8, which specified daily sessions of six hours each on at least five days per week, restricted absences and adjournments and required affidavits of faithful attendance as a prerequisite to the payment of the commissioners' salaries.

The 1868 Commission also was firmly committed to a "codification" of all the laws, which was still a controversial topic. This recommendation, together with the recommended abohition of grand juries and a proposed uniform county government law, may well have disturbed the members of the 1869-70 legislature. In any event, the combination of circumstances resulted in terminating the first commission.

25 The words of the 1868 Commission's recommendation on codification mclude a quote from the provision in the $1846 \mathrm{New}$ York Constitution which is credited to David Dudley Field and which required the appointment of commissioners "to reduce into a written and systematic code the whole body of the law of this state." See Reppy, Davm Dudley Fiemd Centenary EssAYs 37 (1949).

28 Cal. Stats. $1869-70$, c.516 $\$ 2$. 
recommend all such enactments as shall, in the judgment of the Commission, be necessary to supply the defects of and give completeness to the existing legislation of the State, and prepare and present the bills therefor; to examine all special Acts, and such as are confined in their operation to particular counties or cities, and to propose such measures as shall be necessary to give unity and uniformity thereto, and especially to propose, when possible, general Acts, which shall supersede the same; to arrange the statutes in the most systematic and convenient form, and furnish a complete and alphabetical list of the matters contained therem, which, in the future, may be made the basis of an imdex.

No direction to "codify" the laws of the state along the lines of Field's New York work can be read into this statute. In fact, Charles Lindley, who was one of the code commissioners, has conceded that the 1870-74 Code Commission went "a little beyond" the authority granted them by the legislature when they proposed the enactment of the 1872 Codes. ${ }^{27}$ Very little record remains of the internal functioning of the 1870-74 Code Commission, except for the glimpses which can be obtained from reading Lindley's California Code Commentaries. This remarkable work, which covers a period from January of 1872 to January of 1874 , is in part a self-justification by which Lindley sought to convince his readers of the propriety of his convictions. These convictions were so strong that they led to his resignation as a code commissioner on January 5, 1872, on the eve of the adoption of the 1872 codes. This resignation was the culmination of vigorous differences of opinion within the commission and it occurred one month after the convening of the 1871-72 session to which the commission reported. No better summary of Limdley's reasons for resignation can be given than the one in his letter to the legislature in January, 1872, in which he said: ${ }^{28}$

The Codes are not completed. Not one of them, nor a single section or lime, should be adopted until they have had a careful, thorough, patient, professional examination. This examination should be had irrespective

27 Lindley, Caziffornia Code Conmentaries, Appendix p. ii (1872): "The Commission, at my instance, went a little beyond what was contemplated by the Governor when he made the appointments. A revision of the Statutes, and not the expression of a legal system was the scope of the Act and of the appointments. This was all that was contemplated by the other commissioners at the time of our organization. Whatever disapprobation may be thought or spoken against any one on account of the origin of the undertaking to make Codes, let it fall on me, for the fault, if fault it be, is mine and mine alone, except so far as the other commissioners finally concurred. ..." Lindley's comments were also published periodically in 4 Pacific Law Reporter (1872).

28 Id., pp. 5, 6 His impressive cominentaries show that Charles Lindley was a man of wide and studious background who fully understood the nature of the task in which the Code Commission was engaged. His feeling clearly was that a great and momentous project was im danger of being wrecked by the haste with which others were seeking to get the codes enacted. Lindley was a county judge in Yuba County in 1860 (see Cal. Stats. 1860, Res. c.31, p.421), and his appointment to the Code Commission by Governor Haight had been supported by a distinguished list of Northern California lawyers (see Comarentardes, supra note 27, Appendix, p.i). 
of the question of time or expense. A well-perfected system of Codes will be a great blessing and a saving of millions of dollars, while an imperfect one will produce infinite confusion.

Lindley claimed the distinction of persuading his fellow commissioners to recommend a complete set of codes, but said that he had never thought the work could be completed by November 1,1871, the date specified in the statute. In October, 1871, he took his problems to Governor Haight, pointing out that each commissioner had considered carefully only the work which he had done himself, that the completed codes had not been examined in print for the purpose of reconciling them with each other, and that the legislature itself could not hope to examine the codes critically in the time available. He recommended the creation of an "examining board" which could devote its whole time to these matters between November 1, 1871 and March 1, 1872, at which time he hoped that the perfected codes could be adopted. ${ }^{29}$ This recommendation was acted upon by Governor Haight, with the concurrence of the other members of the Code Commission, and'incoming Governor Newton Booth joined in the appointment. According to Limdley, however, this Advisory Board failed to perform any important service from its appointment in October, 1871, until December 20,1871 at which time the legislature had been in session for nearly a month. ${ }^{30}$

The 1870-74 Code Commission may have filed a formal report in 1871, but no copy has been found. They did provide an advance publication of their "proposed codes," however, which bears the somewhat confusing title Revised Laws of California: in four Codes-Political, Civil, Civil Procedure and Penal (1871). These proposed codes are considerably different from the codes as finally adopted by the 1871-72 legislature. ${ }^{31}$ In the fore-

29 Lindtex, California Code Comarentaries 87-88 (1872).

30 Id., Appendix, p.iv. The Advisory Board had no statutory basis and the members were compensated only after the 1871-72 legislature ratified the action of both governors. Cal. Stats. 1871-72, c.12. The members were Charles A. Tuttle of Placer County, the reporter of decisions for the Supreme Court (1863-1867, 1871) and a member of the Senate (1853) and the Assembly (1867-8), and Sidney L. Johnson of San Francisco.

31 Parma and Armstrong, The Codes and Statutes of California: A Bibliography, 22 LAW LIB. J. 41, 42, 48 (1929).

The proposed Penal Code was printed in two editions, one in 1870 (for criticism) and one in 1871. This code was based on the 1850 and 1851 California criminal statutes which were adapted from New York statutes, and it incorporated the work of the New York Code Commissioners. This volume shows Creed Haymond as chairman of the Commission and carries the names of both Charles Lindley (as commissioner) and his son, Curtis H. Lindley (as a secretary). See Cal. Stats. 1862, c.155, indicating their relationship.

The proposed Code of Civil Procedure, printed in 1871, carried the names of all commissioners and was the procedural portion of what was origimally intended to be a Civil Code dealing with both rights and remedies. The proposed Civil Code, published in 1871, carried the names of all commissioners and was based largely upon the New York draft of a Civil Code.

The proposed Pohtical Code, printed in January, 1872, did not carry Charles Limdley's name and contains an extensive foreword describing and justifying the commissioners' work. It includes a demal, for example, that the Commission exceeded the authority given it by the legislature. 
words and annotations to these proposed codes are to be found many comments by the commissioners which may well have served in lieu of any more extensive report. Both the Governor and the Attorney General were favorably impressed with the results of the Code Commission's work, and Governor Booth devoted a portion of his inaugural address to an explanation of the Commission's work and a justification for his appointment of the Advisory Board..$^{32}$ The legislature appointed joint committees to examine the proposed codes and these committees, as well as the Advisory Board, reported in glowing terms that California's adoption of the codes would set "an example which will be speedily followed by all her sister states, adding new laurels to the fame which she has already so justly acquired." 33 The effect of this extravagant praise on the legislature perhaps made the adoption of the codes a foregone conclusion, and, in any event, Lindley was ready to concede that no other result was possible under the circumstances. ${ }^{34}$ Some sections of the new codes were given an advanced effective date although the codes generally were to go into effect on January 1,1873 . The four codes were not published as part of the Statutes of 1871-72 and were not given chapter numbers, due in part at least to the length of time which was needed by the commissioners to put them into shape for publication..$^{35}$

Obvious problems remained, however. The 1871-72 legislature did not pass the bill by which the Commission intended to repeal all of the unneeded legislation antedating the codes. This failure apparently resulted from the fact that the repealer bill, liaving passed in the Senate, came up for final action in the Assembly on the last day of the session and at a time

32 See Assexr. Jour. 126 (1871-72). The Governor said:

"Any one who has often had occasion to examine the statutes of this State will recognize the necessity for their general revision. The report of the Board embraces more than this, and proposes a 'Code of Laws'-pohtical, civil, and criminal-for the entire government of the people of the State." (Italics added).

33 Appendix to Jouratis of Senate and Assembly Nos. 15-19 (1871-72). The joint committees' review of the proposed codes, consisting of some 2400 printed pages of proposed laws was thus accomplished in the two months of January and February, 1872, during the course of a regular legislative session.

34 Lindley, California Code Comarentaries 7 and Appendix, p. vii (1872). Expressions of satisfaction were voiced by members of the legislature who had not favored codification and a telegram of congratulations was received by the legislature from David Dudley Field in New York. See Report of the Code Comanssioners, 6 Appendix to Journats of Senate and AsSEMrbix No. 7, p.6 (1873-74).

35 Special effective dates were set by Cal. Stats. 1871-72, cs.278, 350, 424, 565. Appropriations for the Commission were made by Cal. Stats. 1871-72, cs.202, 508.

CAL. POr. CODE $\$ 4494$, and Cal. Stats. 1871-72, c.350 required a special and separate publication of the codes. The latter also continued the Code Commission until November 1, 1872, for the purpose of publishing, annotating and indexing the codes as well as for the purpose of compiling a publication of the statutes "continued in force," other than the codes. The Governor was also authorized to fill the vacancy caused by Lindley's resignation. 
when unanimous consent was required under the rules to take it up. One objector thus prevented its consideration. The code commissioners subsequently took the position that the failure to repeal the earlier statutes was not of great consequence, presumably on the theory that the implied repeal was sufficient. ${ }^{36}$ In this the commissioners were somewhat overconfident, as later events have demonstrated.

After adjournment of the legislature in early April, 1872, the code commissioners found that a very substantial task lay before them. By April 22, 1872 they had completed the special publication of those portions of the codes given an early effective date by the legislature. They then undertook the compilation of the codes as adopted by the legislature, including the code changes and other enactments of the 1871-72 session. With the burden of work in the state printing plant and the need for copying some 14,165 sections of the codes, the commissioners were unable to complete the publication of the codes by the date set in the statute (November 1, 1872) or by the effective date of the codes (January 1, 1873), and it was March 31, 1873 before the work was done. ${ }^{37}$ Nor was that the end. It was then necessary to compile the Statutes Continued in Force, which the commissioners said somewhat plaintively "are more numerous than is perhaps generally understood." This work, requiring an examination of the statutes passed from 1850 to 1872 , was a labor "fully as great as all the other work done by the commissioners since the adjournment of the legislature." It resulted in a volume referring to every statute theretofore passed, containing some 1,200 pages and listing some 7,000 statutes. ${ }^{38}$ This publication has a basic uncertainty in scope since the commissioners compiled it on the theory that prior legislation on any subject as to which provision was made in the codes was repealed. Thus, the document sets forth at length those statutes which the commissioners thought were still in effect and not covered in any way by the codes. But literally hundreds of presumably superseded statutes are listed, some of which are identified as having been repealed by specified parts of the codes but most of which are merely listed without any identification of conficting code provisions. Unfortunately, from the viewpoint

38 CAL. Pox. CODE $\$ 4505$ refers to the contemplated repeal of earlier conflicting statutes, and in their annotation to this section the code commissioners concluded, with respect to the repealer bill, "Non-action upon it will not affect the code in any particular." Sce ANNOTATED CIVIL CODE, Appendix 590 (1872).

37 The code commissioners reported in soine detail, in their final report, concerning the magnitude of this work. See, REPORT OF CODE COMMIISSIONERS TO GOVERNOR Bootr (Nov. 15, 1873), 6 APpendIX to JournaIS of SENATE AND ASSEMBLy No. 8 (1873-74); and REPORT of Code Commasstoners (Feb. 28, 1874), 6 Appendix to Journats of Senate and Assembly No. 7 (1873-74).

38 Statutes Continued IN Force (1873) was printed by the State Printer. It has an 1873 date of publication and probably was available about November 1, 1873, just prior to the commencement of the 1873-74 session of the legislature. 
of statutory certainty, the California courts have refused to give any weight to the conclusions of the code commissioners on this point and have reserved the right to decide in each situation whether or not an implied repeal existed by reason of the enactment of the codes in $1872 .^{39}$ Thus, the specter of pre1872 legislation has haunted the California statute law for eighty years and has seriously impaired the effectiveness of several of the later attempts to revise our codes.

The 1871-72 legislature, as an addition to the duties already required, instructed the code commissioners to recommend needed changes in the codes at the next session. It is clear that a substantial dissatisfaction with the codes existed almost from the time of their adoption. This led to the appointment in June, 1873, of yet another committee "to examine the codes." ${ }^{40}$ This committee, appointed by Governor Newton Booth, consisted of Stephen J. Field, who was then an associate justice of the United States Supreme Court; Jackson Temple, who was an ex-justice of the California Supreme Court; and John W. Dwinelle, an outstanding San Francisco attorney who had been one of the signers of the 1850 petition seeking the adoption of a civil law or code system in Califormia. This committee, working with the staff of the Code Cominission, reported to the Governor on October 11, 1873. They recommended a number of minor amendments to the codes, but by and large they found the codes to be "perfect in their analysis, admirable $\mathrm{m}$ their order and arrangement, and furnishing a coinplete code of laws." ${ }^{41}$ This endorsement of the work of the code commissioners was specially noted by them in their final report to the 1873-74

39 Statutes Continued IN FORCE, as published by the 1870-72 code commissioners, was intended to identify all of the acts preceding the 1872 codes which were either in force or superseded by the codes, but the courts refused to give weight to the commissioners' conclusions even where they clearly specified an act as having been necessarily repealed by implication. (See Needham v. Thresher, 49 Cal. 392 (1874) and Statutes Contivued in Force, supra, § 664, p.361. Cf. People v. Talle, 111 Cal.App.2d 650, 245 P.2d 633 (1952), relating to Cal. Stats. $1865-66$, c.644, which was thereafter codified in 1953 as CAL. PEN. CoDE $\S 1323.5$ by Cal. Stats. 1953, c.50. The 1872 code commissioners undoubtedly thought this act was superseded by the Penal Code, as indicated in their Annotated Penal Code $\S 1323$, p.457; see also Index to Law of Cartrornia 710 (1894) and INDEX to the Laws OF CaLIForNIA 78, 93 (1921).

In the absence of a later specific repeal by the legislature, a court decision is thus required in order to determine which of the pre-1872 statutes were repealed by the adoption of the codes. This fact has been recognized in all indices of statute law published since that time and was a major factor contributing to the confused state into which California's statute law had fallen by 1929 .

40 This dissatisfaction was commented on by the commissioners in their final reports and they attributed it to public misunderstanding. Lindley considered the appointment of an examining committee to be a "pressing necessity" compelled by the fact that the 1871-72 legislature had acted hastily and unwisely in adopting the codes before they were carefully checked and perfected. IINDLEY, CaLIFORNIA Code CoManentaries 33 and Appendix, p.v (1872).

41 Report of Comatrsstoners to Examine the Codes, 4 Appendix to Journais of Senate AND AsSEMrBLY No. I (1873-74). Mäterial relating to this coinmission was reprinted in 1916 by the State Librarian in Tre CoDE EXAMriners' Notes. 
legislature, and Governor Booth referred to the committee's work in his inaugural message. ${ }^{42}$ At the 1873-74 session of the legislature money was appropriated to pay the Code Commission and its staff, as well as the members of the Field Commission, for the work which had been done on the codes without legislative authorization. ${ }^{43}$ In addition, some 468 pages of amendments to the codes were adopted, as well as some 957 pages of statutes not directed to the codes. The 1872 codes had been separately published, and the 1873-74 amendments were published as a separate document, pursuant to the legislature's direction.4t

At the conclusion of the 1873-74 legislature, the work of the existing commission was finished. The job of perfecting our statute law was, in the eyes of that legislature, complete. The several bills which were introduced for the purpose of continuing the work of statutory revision and codification were therefore unsuccessful. Charles Lindley offered a final recommendation in January, 1874, which is worth examining in some detail, particularly in the hight of later events. His recommendations were not in tune with the times, of course, since he was strongly of the opinion that our code system was in need of a great deal of additional work. But in his California Code Commentaries he laid down a series of basic principles for codification which sound very modern in the light of our experience in California since $1929 . .^{45}$ As an appendix to the Commentaries there is printed a letter to ex-Governor Henry Haight, who had appointed him to the Code Commission, in which Lindley made a strong plea for a permanent agency to carry on a continuous, expert program for improving and strengthening the codes. He urged the use of law school faculties and noted that, unless future acts of the legislature were integrated into the code system by some such technique, the destruction of that system was inevitable. He foresaw ten

42 Governor Booth indicates that the justices of the Supreme Court were concerned enough to urge that a special examination of the codes be made. See AssEM. Jour. 139 (1873-74).

43 Cal. Stats. 1873-74, c.352, provided for the Code Commission salaries; and Cal. Stats. 1873-74, c.353, provided for the Field Commission salaries.

44 Cal. Stats. 1873-74, c.574.

45 Lindley's principles of codification include: logical classification of statutes by subject matter, short sections, only one expression of a particular rule rather than conflicting statements of the same rule in different codes, a prohibition against use of two or more synonymous words to express a single idea, rigid consistency in the use of language, scrupulous examination and re-examination of draftsinanship prior to enactment, preparation of specific repeals of prior legislation with unremitting care, and preservation of the system by making all new legislation a logical part of the code system.

By careful analysis Lindley demonstrated the inadequacies of the 1872 codes when measured by these tests. In this Lindley preceded such eminent scholars as Sir Frederick Pollock who commented that the Field Civil Code was "about the worst piece of codification ever produced." See Lewinsohn, Law Reform in California, 3 Carm. L. Rev. 300, 305 (1915) ; compare Harrison, The First Half-Century of the California Civil Code, 10 Carrf. L. Rev. 185 (1922); Pomeroy, The True Method of Iriterpreting the Civil Code, 3 and 4 WEST COAST REPORTER (1884). 
to twenty years of continuous effort by an expert staff as the indispensable requirement of a perfected system of codes. Charles Lindley was, as we have seen, far ahead of his time. The legislature was not interested in the long range problem and was satisfied, on very good authority, of the substantial perfection of the job which had been done.

The 1872 codes were published as separate documents by the State Printer and sometime thereafter a private publication was offered by $\mathrm{H}$. S. Crocker \& Co. which contained annotations by the code commissioners. ${ }^{46}$ No other state publication of the 1872 codes was ever made, according to the study made by Parma and Armstrong in 1929.47 Private publishers of the codes and statutes were not long in discovering the difficulties caused by the failure to repeal the legislation preceding the 1872 codes, by the ambiguities in the commissioners' publication of Statutes Continued in Force, and, as time passed, by the failure to integrate current legislation into the code system. ${ }^{43}$ These were defects which cumulated in effect as the years passed.

C

COMMISSIONS FOR THE REVISION AND REFORM OF THE LAW (1880-1911)

There was, understandably, no interest in the legislature for several sessions in the problem of statutory revision. The adoption of the 1879 Constitution, however, presented some serious problems in the adaptation of our statute law to the new constitutional provisions, and these problems confronted the legislature which convened in January, $1880 . .^{49}$ Outgoing Governor William Irwin, having anticipated this problem, appointed a commission of three members to revise the codes in order to conform them to

40 The final report of the code commissioners to the legislature contains a careful explanation of the need for private publication of the annotated codes, including the fact that no profit was made thereby. Supra note 37 .

47 Parma and Armstrong, The Codes and Statutes of California: A Bibliography, 22 LAw Lm. J. 41, 42 (1929).

48 A typical comment is the one in Hitreml's Codes and Statutes of Calmfornta (1876). In Volume 2, at 1403, he observed:

"The statutes in force consist of such as were expressly continued in force by the codes, such as related to subjects not embraced in the codes, and such as have been passed since the adoption of the codes. In some, and indeed in many cases, owing to the incomplete manner in which the work of repeal and supersession has been done, it is difficult to determine wbat is in force and what has been superseded; and in most of these cases no certainty will be arrived at, until further action by the legislature or final adjudication in respect to them by the supreme court .... It may be here added, what however has probably already struck the reader of the above remarks, that our system of statute law is, in many respects, very far yet from being reduced to anything like uniformity or proper order."

49 The 1879 Constitution, which was adopted by the voters in May, 1879, provided for a session of the legislature commencing in January, 1880, and for one commencing in January, 1881. Thereafter the regular general sessions have been biennial, commencing in January of each odd-numbered year. See CaI. Constrtution Art. TV, §§ 2, 3 (1879). 
the new Constitution. He recommended that the 1880 legislature compensate the members of the commission for their time and effort and emphasized that no changes in policy liad been made. His recommendations were concurred in by mcoming Governor George C. Perkins, and the legislature appointed a six inember joint committee to confer with the commissioners. ${ }^{50}$ Finally, in 1881, a bill was passed making an appropriation to pay the commissioners for the work done "in preparing bills adapting the Codes of this State to the present Constitution." 51 Commencing in 1881 the "amendments to the codes" were combined in the same volume with the statutes passed at eacli session, and that practice has continued to the present time. Since the volume of statutes not directed to the codes far exceeded the volume of amendments to the codes from the beginning, it lad become clear that the publication of separate volumes served no useful purpose.

At every biennial session of the legislature from 1883 to 1893 measures were presented which reflected the need for a permanent code revision agency of some kind, but these attempts were universally unsuccessful. These measures proposed permanent commissions, temporary commissions, commissions of single members and advisory groups. Commencing in 1893 the interest in statutory revision mcreased markedly, which is understandable in view of the lapse of twenty years since the work of the 1870-74 Code Commission. The 1893 legislature directed the State Printer to compile a complete index to all the laws of California from 1850 to $1893 .^{52} \mathrm{In}$ addition to the usual bills to create a commission to revise the laws of the state, two unsuccessful bills were offered to create a committee on proposed legislation to advise the legislature, with power to hold hearings on proposed bills in advance of the meeting of the legislature. The State Printer's index, prepared in response to the legislature's request, is an exceedingly valuable and comprehensive document. It was published in 1894 and it indexes all legislation passed by the California Legislature from 1849 to 1893. In addition, the book contains tables which constitute a kind of "statutory record" listing specific action of the legislature affecting the measures indexed. ${ }^{53}$ The 1894 Index to the Laws of California also contains a list of

505 Appendix to Journats of Senate and Assembly (1880). The commission consisted of Messrs. I. S. Belcher, Thomas P. Stoney and A. C. Freeman. Belcher was a Supreme Court Justice in 1872 and a Supreme Court Commissioner from 1885 to 1898 [CALIroRnis BLUE Book 682, 685 (1909)]. A. C. Freeman was also a code commissioner from 1899 to 1903 and a member of the 1879 constitutional convention. He was the author, among other works, of FreEman on JuDGMENTS.

The legislature's appointment of a joint committee was provided by Cal. Stats. 1880, Res. c.13, p.555. No reports of either the commission or the legislative committee have been found.

51 Cal. Stats. 1881, c.32.

52 Cal. Stats. 1893 , c.136.

53 The term "statutory record" came into Cahifornia usage in 1933 when the Legislative Counsel prepared a chapter-by-chapter listing of all acts of the legislature for the 1929 Code Commission, showing each of the later statutes having a specific effect on the acts listed. See Statutory Record, Legislative Counsex (1933); Statutory Record Supplemenent, LegistaTVF Comser $(1948) \cdot$ and session law volumes thereafter 
the pre-1872 statutes thought to have been impliedly repealed by the adoption of the codes. This list was assembled from the repealer bill prepared by the 1870-74 Code Commission, but as has been indicated, such lists have not been given authoritative status by the courts. ${ }^{54}$

Possibly as a result of the conditions disclosed in the preparation of the 1894 index, a substantial body of opimion had developed by 1895 in support of a revision of our code system. Outgoing Governor H. H. Markham found time in his address to the 1895 session of the legislature to urge legislation permitting the Governor to appoint a three member commission for this purpose. ${ }^{55}$ The Assembly Judiciary Committee authored the bill which became Chapter 222 of the Statutes of 1895 , creating a three member commission to revise all the statutes of the state. This act provided for a non-partisan permanent commission whose members were appointed by the Governor for two-year terms commencing on April 1, 1895. The members were required to be lawyers who had been admitted to practice before the Supreme Court of California for more than five years, and they were to be paid at the rate of $\$ 4,000$ per year. The commission was directed to revise the four 1872 codes and all statutes passed by the legislature; and it was given broad power to recommend any changes in the statutes which were thought desirable. Fimally, the commissioners were directed, when requested by the legislature or any committee thereof, to attend at sessions of the legislature and act as "legislative counsel or adviser, in drafting or passing upon the form of any bill, or proposed bill, pending or to be introduced before the legislature."

The report of this first "commission on revision and reform" was in print by December 5, 1896, about a month in advance of the 1897 session of the legislature. The report, which was the work of two of the members, comprises some 304 pages and recommends changes in each of the 1872 codes. The commissioners mdicated that their aim was to incorporate the "statutes in force" into the codes, but that their work was far from complete. ${ }^{56}$ An examination of the statutes enacted at the 1897 session indicates that only a few of the commission's proposals became law, although the Assembly created a standing committee of five members to take charge of

54 Supra note 39.

55 Governor Markham referred to the fact that there had been no revision of consequence since 1873, and said, "it would seem essential that the many laws passed and amendments made to the codes themselves simce that date should be codified into a harmonious whole." See 1 Appendix to Journais of SenAte and Assembly (1895).

56 REPORT OF THE COMMTISSTONERS FOR THE REVISION AND REFORM OF THE LAW (1896). See Appendix to Journats of Senate and Assemsbly (1897). The commissioners were Frank T. Baldwin, Ryland B. Wallace and J. C. Daly. 
the bills resulting from the commission's work. ${ }^{57}$ Two bills were introduced in 1897 for the purpose of repealing the act creating the commission, and one bill would have replaced the commission with a single commissioner. None of these proposals was acted upon favorably, and the legislature appropriated funds to pay the expenses of the commission over and above the salaries provided in the act creating it. ${ }^{58}$

Three new commissioners were appointed by Governor Budd following the 1897 session, all of whom were members of the legislature at that session. He appointed two Democrats, A. Caminetti and T.W. H. Shanahan, and one Republican, Robert N. Bulla ${ }^{60}$ The report of this commission, the second Budd "commission on revision and reform," was printed and bears the date of November 30,1898. The report is in two volumes, one being a complete revision of the Civil Code and the other constituting a proposed addition to the Political Code dealing with the subject of municipal corporations. ${ }^{60}$ A new Republican governor, Gage, was mauguated in January, 1899, and a completely, new commission was appointed in July, 1899. While the 1899 legislature did not accept the work of the 1897-99 commissioners, it did make adequate provision for the commission for the two fiscal years commencing on July $1,1899 .{ }^{\text {B1 }}$

The third "commission on revision and reform" retained a stable membership through the 1903 session of the legislature and throughout Governor Gage's incumbency, and many of its recommendations ultimately found their way into our statute law. The first report of this commission was in three parts, which appeared on August 1, September 1 and October 1, 1900. Substantial amendments were proposed to the Code of Civil Procedure, the Civil Code and the Penal Code. The commissioners stated their

57 The provision for an Assembly Committee on Revision of Codes and Statutes was added to the standing rules. See Assem. Jour. 23 (1897).

68 Cal. Stats. 1897 , c.209, appropriated $\$ 1,221.89$ for the commission's expenses.

69 Caminetti served in both the Assembly and the Senate over a period from 1887 to 1913 ; Shanahan served in the Assembly from 1887 to 1897; and Bulla served in both houses during the period from 1893 to 1899. At that time Section 19 of Article IV of the Cahifornia Constitution only prohibited a legislator from accepting a state civil office of profit which was crealed (or the emoluments of which were increased) during the term for which the legislator was elected.

60 See Appendix to Journats of Senate and Assembix Nos. 15, 16 (1899). This report covered 742 printed pages and was very ambitious in its coverage.

$61 \mathrm{Few}$, if any, of the commission's recommendations were enacted although Assemblyman Caminetti's bill designed to require the judiciary committees to incorporate all "general law" bills into the code system was passed. See Cal. Stats. 1899, c.129, adding $\$ \S 248,249$ and 250 of the Cax. Pox. CoDE. Senate Bill 622, which would have paid the commission's expenses for 1897-1899, was not signed by Governor Gage although it passed both houses.

The general appropriation bill provided the commission with upwards of $\$ 37,000$ for the two years which commenced on July 1, 1899. See Cal. Stats. 1899, c.95. The new commissioners were A. C. Freeman (supra note 50), George J. Denis and W. C. Van Fleet (former Supreme Court Justice). 
purposes as follows: (1) to eliminate code sections which overlapped but apparently conflicted with constitutional provisions; (2) to eliminate duplicating or inconsistent sections as between the codes; (3) to incorporate independent statutes into the four codes; and (4) to make non-controversial, but needed, changes in substance. More than one-fourth of the Code of Civil Procedure was to be amended or repealed, and a substantial codification of independent statutes was found to be needed in the Penal Code. ${ }^{62}$

At the 1901 session the Senate followed the Assembly's lead and created a Standing Committee on Code Revision. The Assembly Committee on Revision and Reform of the Laws, however, introduced the three bills needed to effectuate the recommendations of the commission which became, respectively, Chapters 102, 157 and 158 of the Statutes of 1901. Each bill was drafted as an act to revise the code involved, by amending, repealing and adding sections. This attempt to combine the commission's recommendations into three bills proved fatal for, in Levis v. Dunne, ${ }^{63}$ the Califorma Supreme Court held that the commission's bill revising the Code of Civil Procedure was void upon two constitutional grounds: first, that it attempted to revise the code without re-enacting and publishing it at length; and second, that it did not deal with a single subject, expressed in its title. ${ }^{64}$

The second report of the Gage commission on revision and reform of the law appeared on November 1, 1902, in preparation for the 1903 session of the legislature. It consisted of two parts and contained the commission's revision of the Political Code and an index of the statutes from 1895 to 1901, as requested by the 1901 legislature. The commissioners renewed their 1901 recommendations and prepared separate, single-subject bills to enact their proposals with respect to all four codes. They concluded that the work contemplated by the 1895 act creating the commission was finished, and recommended the repeal of that act. Their report included forty-six pages of fine print, listing the "statutes remaining in force" outside the codes, although the commissioners characterized this list as "exceedingly brief." ${ }^{15}$ Bills to carry out both the 1901 and the 1903 recommendations of the commission were imtroduced by the Senate and Assembly committees, but the practical problem of considering the 364 bills which

62 REPORT OF COMOMISSIONERS FOR THE REVISTON AND REFORMI OF THE LAW, 3 vols., 470 pp. (1900); Appendix to Journats of Senate and Assenrbix (1901).

63134 Cal. 291, 66 Pac. 478 (1901).

64 Car. Consr. Art. IV, $\S 24$, imposes these requirements. The commissioners appeared in the Lewis case as amici curiae, but the court was not impressed either with the authorities presented or with a recital of the practical difficulties which the legislature would face if the commission's recommendation had to be presented in the form of many separate bills. This decision, of course, had the effect of invalidating the 1901 revisions of the Civil Code and Penal Code, as well as the revision of the Code of Civil Procedure.

65 REPORT OF COMMIISSIONERS FOR THE ReViston AND REFORM OF THE LAW, 2 vols., 599 pp. (1902); Appendix to Journais of Senate and Assembix (1903). 
were needed, in a session which lasted from January 5 to March 14, proved insuperable. On January 22, 1903, the Assembly Committee on Revision and Reform of the Laws filed a report in which it estimated that about 273 hours of legislative time would be required for the consideration of these bills in the Assembly. A resolution was adopted, placing the commission's bills on a special "Code Revision File" so that the house could take them up on motion at any time. ${ }^{66}$ On March 6 and 7, 1903, an attempt was made to take up the special second reading file of commission bills then pending, but the motions were defeated. ${ }^{67}$ The revision program was thus stalled for the time being. ${ }^{.8}$

The 1903 legislature, which had been advised by the revision commissioners that the act under which they worked could now be repealed, did not agree that the need for such an agency was past. Chapter 362 of the Statutes of 1903 revised the 1895 act under which the various revision commissions had operated and set the pattern for the next several years by providing for a commission consisting of a single commissioner. This change was probably dictated by considerations of economy and a biennial appropriation of $\$ 10,850$ was made, in place of the $\$ 37,000$ appropriation required in 1899 and the $\$ 35,000$ appropriation required in $1901 .^{60}$ The commissioner was directed to continue the work of revision along the lines previously charted, including the codification of statutes not previously incorporated into the code system. The commissioner was given a two-year term, commencing on May 1, 1903, and the act was to terminate on May 1, $1905 .^{70}$

The new commissioner, appointed by incoming Governor George C. Pardee, was John F. Davis. He had served as judge of the Superior Court of Amador County and had been a member of the state Senate during the 1899 and 1901 sessions. His report to the 1905 legislature, which was printed in November, 1904, consisted of an index to the statutes of California from 1895 to 1904, a table of the code sections affected by legisla-

68 ASSEM. JoUR. 201, 1271 (1903).

67 These motions were made at a time when the resolution for adjournment sine die was pending. See ASSEM. Jour. 1340, 1374 (1903).

$68 \mathrm{~A}$ different kind of attack was made on the problem, however, by Assembly Constitutional Amendenent No. 26, which became Cal. Stats. 1903, Res. c.39, p.742. This amendment proposed to add a new section to the California Constitution which would exempt code revision bills from the requirements of Section 24 of Article IV. This attempt was defeated at the polls in 1904 by a vote of 59,050 (for) to 59,933 (against).

60 The appropriations were made in the respective general appropriation acts: Cal. Stats. 1903, c.380; Cal. Stats. 1901, c.163; Cal. Stats. 1899, c.95.

70 The 1903 revision also required the commissioner to attend sessions of the legislature and to act as "legislative counsel or advisor." He was instructed to examine all supreme court decisions affecting the statutes and to give advice to the legislature and its counmittees, when requested, as to constitutionality and legal effect. Cal. Stats. 1903, c.362, $\$$. The requirement was added that an index be compiled and that a new county government act be prepared. 
tion during that period and a list of the statutes remaining in force. ${ }^{71}$ Both houses of the legislature retained their standing committees on code revision and, confronted with the unavoidable necessity for considering the revision proposals item-by-item, the 1905 session did a creditable job of enacting the 1901 proposals into law, at least insofar as the Civil and Penal Code recommendations were concerned. ${ }^{72}$ This was accomplished by providing a special file for the code revision bills and by setting special evening sessions at which these revision bills could be considered. The code revision committees filed special reports in advance of the consideration of these special files in which a brief description was given of the various bills pending on the file. ${ }^{73}$ The legislature appropriated money for the continued operation of the commission at the same level as it did in 1903, and extended its termination date from May 1, 1905 to May $1,1907 .{ }^{74}$ Governor Pardee's niessage to the 1905 legislature contains a few sentences which are reminiscent of the words of earlier Governors. He said: ${ }^{75}$

It is now more than thirty years since the codes were adopted, the principal object at the time being to rescue the law from the uncertainty of many conflicting statutes and decisions. It was recognized that there were objections to the code system, and in practical operation it does not realize all that was claimed for it by its advocates; but it has been a great improvement upon what existed before, and no one proposes its abandonment.

But it is well known that the codes have not been improved and perfected to the extent they should be, and at each session many general statutes are passed embodying matter which ought to be incorporated in the codes. The imtegrity of the codes should be respected, and the system kept as symmetrical as possible.

The commissioner's report to the 1907 session of the legislature was merely an extension of that printed in 1905. Entries were added to the index, to the table of code sections affected and to the table of statutes remaining

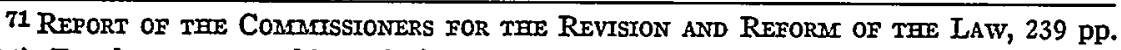
(1904). For the most part, this work simply involved adding to the prior reports the legislation passed in 1903. Possibly one of the reasons for not recommending specific legislation was the pendency of the ballot measure which, if adopted, would have permitted the kind of omnibus revision bill which the Supreme Court bad invalidated in 1901.

$72 \mathrm{~A}$ spot check indicates that most of the 1901 recommendations affecting the Civil Code and Penal Code were enacted. See tables contained in Cal. Stats. 1905, pp. 1109-1122, 1123-1140. The Senate committee introduced the bills affecting the Penal Code and the Assembly committee introduced those affecting the Civil Code. Of 613 chapters enacted at the 1905 session, 83 were code revision bills.

73 For special file resolutions, see ASSEMr. Jour. 320 (1905), and SEN. Jour. 672 (1905). For special committee reports, see Assear. Jour. 482, 683, 1050, 1426 (1905); SEN. Jour. 393, 561,803 (1905). Commissioner Davis was granted the privileges of the floor during the consideration of these bills. See Assem. Jour. 745 (1905).

74 Cal. Stats. 1905, c.563 (general appropriation act) and c.343.

75 Assear. Jour. 11 (1905). 
in force. ${ }^{70}$ This session of the legislature followed the pattern set by its predecessor, except that the enactments affected primarily the Code of Civil Procedure and the Political Code. The direction contained in the 1903 amendments, which required the commissioner to prepare a codified county government act, resulted in the enactment of Chapter 282 of the Statutes of 1907. The legislature extended the termination date of the commission to October 1, 1911, and made the usual biennial appropriation. ${ }^{77}$

A special provision was made by the 1907 legislature with respect to the index of state laws. Each of the various commissions for the revision and reform of the laws had published supplements to the 1894 index, but the legislature now authorized the preparation and publication of a recompiled index, covering the entire period from 1850 to 1907 . This index was published in 1908 by the State Printer and constitutes a complete, cumulative record of the statutes enacted during the period involved. ${ }^{78}$ The index bears a publication date of September 30,1907, coinciding with the end of Mr. Davis' term of office. Governor Gillette thereupon appointed J. W. Wiley of Bakersfield as Commissioner for the Revision and Reform of the Law and renewed the appointment for a second two-year term in October, 1909 , thus perpetuating the practice by which each Governor selected his own commissioner or commissioners for the period of his incumbency. ${ }^{70}$

At the 1909 session of the legislature, a report was presented by Commissioner Wiley which concentrated on the incorporation into the codes of many independent statutes. Some 178 bills were introduced in the Assembly and 20 bills were introduced in the Senate to carry out the recommendations of the commissioner. ${ }^{80}$ Again, no special consideration was given

76 REPORT OF THE COMAIISSIONER FOR THE Revision AND REFORM of tHe LAW, 301 pp. (1906).

77 The Assembly, which retained its code revision committee, did not set up any special file, but handled the code revision bills in the ordinary course of business. The Senate dropped its standing code revision committee, SEN. JouR. 7, 80 (1907), and the bills were handled by a subcommittee of the Judiciary Committee.

See Cal. Stats. 1907, cs.282 (county government act codification), 234 (extension of commission) and 475 (general appropriation act).

78 Cal. Stats. 1907, c.301. In addition to the index, the volume contains a list of the code sections affected by subsequent legislation and the notes of Commissioner Davis with respect to the code revisions made in 1905 and 1907 , mcluding the county government codification. It also repeats the tables of statutes presumably in force and statutes presumably repealed by the 1872 codes. See Index to the Laws of CarifornaA, 1057 pp. (1908), by John F. Davis, Commissioner for the Revision and Reform of the Law.

70 The practice is illustrated by the following table:

Governor

Budd (1895-1899)

Gage (1899-1903)

Pardee (1903-1907)

Gillette (1907-1911)
Revision Commission

First Revision Commission (1895-1897)

Second Revision Commission (1897-1899)

Third Revision Commission (1899-1903)

Davis (1903-1907)

Wiley (1907-1911)

80 Report of CoMamissioner for Revision and Reforar of tHe Law, 87 pp. (1909). The Assembly bills were introduced by the chairman of the standing committee on revision (see A.B. $321-372,515-562,849-906$ and $1287-1509$ ). The Senate bills were S.B, $1109-1129$. 
these bills on the file of either house, with the result that all of the Assembly bills died in committee or on file and only six of the Senate bills were enacted into law. The legislature did appropriate money for the commissioner during the succeeding biennium, however, and increased the salary of his stenographer. ${ }^{81}$ No report to the 1911 session of the legislature was found, perhaps because the recommendations previously made had not yet been acted upon. Again the Assembly chairman of the revision committee introduced some 120 bills and there were some 100 bills introduced in the Senate. $^{82}$ In this session none of the bills relating to revision of the laws passed, and only a few of the Assembly bills were favorably reported out of committee. An unsuccessful attempt was made to extend the life of the commission beyond the October 1, 1911 termination date, but the legislature appropriated only enough money to pay the salaries of the commissioner and his stenographer to that date. ${ }^{83}$

With the conclusion of the 1911 session of the legislature there ended the drive for revision of the statutes which had commenced in 1893. Most of the recommendations which were inade between 1895 and 1901 were finally enacted into law, and the state index of 1908 gives an accurate picture of these accomplishments since very few of the later recommendations were enacted. The statutes still in force, outside the four codes, were listed in 66 pages of fine print and very hittle reduction had taken place in the list of statutes presumably repealed by the code amendments. The situation was comparable to that which existed in 1875 when the legislature completed its work on the original codes, and the 1911 legislature was similarly unenthusiastic about the need for any continuing attention to the problem of statutory codification and revision. The stage was set for another period of quiescence, sure to be followed by another discovery of the need for revision.

D

LEGISLATIVE COUNSEL AND STATUTORY REVISION (1913-1927)

The 1913 session of the legislature, which was the second session of Hiram Johnson's first term as governor, lasted considerably longer than any of its predecessors and found itself somewhat overwhelmed by the magnitude of its task. One of the remedies proposed involved the creation of a "legislative reference and legislative counsel bureau" to assist the leg-

81 Cal. Stats. 1909, cs.659 (stenographer's salary) and 725 (general appropriation bill).

82 See A.B. 438-462, 1208-1281, 1407-1437 and S.B. 310-335, 794-867.

83 Cal. Stats. 1911, c.705 (general appropriation bill). 
islature in handling the heavy volume of legislation. ${ }^{84}$ Several bills were introduced in each house to carry out this recommendation, but a bill introduced by Assemblyman W. C. Clark of Oalsland was finally enacted into law after avoiding defeat in the Assembly by a narrow margin. Clark's proposal was based upon detailed research concerning the Wisconsin and Indiana Legislative Reference Bureaus, but, as enacted, his bill provided only for the creation of the Legislative Counsel's office and for the bill-drafting and statutory revision function. ${ }^{85} \mathrm{It}$ is apparent from reading this statute, which became Chapter 322 of the Statutes of 1913, that the primary concern of its authors was the provision of technical assistance to the legislature during sessions. It is worth noting that the function of providing legal counsel and advice during sessions can be traced back to the 1895 revision commission which had that duty, as did its various successors through the 1911 session. The responsibility for revision of the statutes, while mentioned, was only incidental to the other duties of the office, as contrasted with the statutes under which the several revision commissions had operated. The first Legislative Counsel, Arthur P. Will of Los Angeles, was selected in 1914 by a five-member Legislative Counsel Board which consisted of the Governor or his appoimtee and two members of each house. ${ }^{88}$ Both the 1915 and 1917 sessions made minor changes in the statute creating the Legislative Counsel's office. ${ }^{8 \tau}$ Following Mr. Will's resignation in

84 See Hichiorn, StoRy of THE CatIFORNIA Legistature of 1913, 357-59 (1913). Hichborn's studies of the 1909 and 1911 sessions indicate that the struggle for political power which culminated in Hiram Jolnnson's election in 1910 may well bave blotted out the code revision program in those sessions simply because of the demands of more compelling business.

An interesting report was filed at this 1913 session by a selected committee consisting of the chairman and two inembers of the Senate Judiciary Committee. SEN. Jour. 663, 754 (1913). The committee concluded that Cax. Por. CoDE $\$ \$ 249$ and 250 (see note 61 supra), were unconstitutional insofar as they purported to require the Senate committee to place all "general law" bills into the California code system. Only the Senate itself had that power under the Constitution, in the committee's opinion. These sections were finally repealed in 1937, Cal. Stats. 1937, c.80; see AsSEMr. Jour. 80 (1937).

85 Clark's A.B. 970 as introduced, provided for a bureau with two divisions, each under a chief. One division was to deal with the collection of factual research materials and tbe othcr was to handle the preparation of bills and the necessary revisions of the statute law. According to Hichrorn, Story of THE CAIIFORNIA Legistature of 1913 (1913), the State Librarian and the Board of State Library Trustees felt that the legislative reference function slould be vestcd in the State Library. This opposition led to a defeat of the bill on the Assembly fioor, but it was revived and after the reference function was amended out, the bill passed without further difficulty. See Assens. Jour. 1321, 1879, 2204, 2250, 2343 (1913).

The other bills were: (1) to establish a "legislative council," A.B. 994 and S.B. 872 ; (2) to establish a "legislative reference and counsel bureau," S.B. 951; and (3) to establish a legislative reference bureau in the State Library, A.B. 1687, A.B. 1930 and S.B. 1490.

86 See CaLIFORnIA BLUE Book 521 (1915). During the period 1914 to 1917 the Legislative Counsel Board consisted of three Assembly members (one representing the Governor) and two senators.

87 Cal. Stats. 1915, c.41, added the duty of drafting initiative measures at the request of 25 electors. Cal. Stats. 1917, c.727, abolished the "legislative counsel board" and gave the power of appointinent to the Governor. The latter statute also restated the interim duties of the office and emphasized the work of statutory revision. 
September, 1920, three different men served as legislative counsels for the sessions of 1921, 1923 and 1925: George B. Bush of Riverside, John A. McGilvray of Sacramento and Thomas M. Gannon of Sacramento. ${ }^{88}$ From 1917 on, the position was a pleasure appointment of the Governor, and each Governor found it expedient to select his own legislative counsel. An index of state laws called for by the legislature in 1917 and 1919 was finally completed and published in $1921 .^{89}$

Many of the resolutions and acts passed by the legislature between 1915 and 1925 which called for work in the field of statutory revision were directed to the Legislative Counsel. They called for a study and report concerming the statutes in such diverse fields as those concerning highway laws, insurance laws, general corporation laws, municipal corporation laws, school laws, and special assessment district laws. Several attempts were made to secure a study by the Legislative Counsel of the systems used in other juridictions for the compilation and codification of statute law. ${ }^{90}$ No provision was made for augmenting the Legislative Counsel's very small staff in connection with any of these projects, however. With one exception, therefore, the record of those sessions does not show that the requested reports were subnritted, and when the 1925 legislature decided to undertake a revision of the statutes governing criminal procedure, it created a commission for that purpose. ${ }^{91}$ In 1926 Legislative Counsel Thomas $M$. Gannon completed the supplement to the 1921 state index which was called for by Chapter 208 of the Statutes of 1925, and during that bienniun he

88 The terms of office were: Will, May 18, 1914 to September 20, 1920; Bush, September 20, 1920 to January 9, 1923; McGilvray, January 9, 1923 to July 2, 1923; Gannon, November 1, 1923 to January 4, 1927. CalIForala BlUE Book 429 (1924).

89 INDEX to THE LAwS OF CALIFORNIA, 1288 pp (1921) by Legislative Counsel George B. Gush. See Cal. Stats. 1917, Res. c.52, p.1941. This direction was repeated more emphatically in 1919 by Cal. Stats. 1919, c.473. In addition to the index, this volume contains a statutory record of amendments to the codes and general laws and the usual list of probable repeals by implication. No attempt is made to list the "statutes in force" outside of the codes.

For the first time, the journals of the 1921 legislature indicate the assignment of extra duties to the Legislative Counsel during the session. The LEgISLative DigesT, which summarizes bills introduced during the January part of the session, was first authorized by this legislature. See Assear. Jour. 245, 533, 2135, 2522 (1921); SEN. Jour. 237, 498, 1822, 2319 (1921).

${ }^{00} \mathrm{~A}$ report on highway laws was requested by Chapter 12 of the Statutes of 1919, and the Legislative Counsel's report is printed in SEN. Jour. 178-192 (1921). The ineffective requests for a study and report upon a system for coinpilation and codification were made by Cal. Stats. 1921, Res. c.68, p.2200 and Cal. Stats. 1925, Res. c.65, p.1398.

01 Cal. Stats. 1925, c.346. This act appropriated $\$ 10,000$ for the purpose of making the desired study. The absence of an appropriation undoubtedly explains the failure of the Legislative Counsel to undertake some of the earlier projects assigned to him. Note that the 1921 index was completed only after the legislative made a special appropriation of $\$ 6,000$ for that purpose. Appropriations for the Legislative Counsel's office ran consistently at about $\$ 20,000$ to $\$ 25,000$ per biennium from 1913 to 1927 , except for a few extra appropriations for special projects such as the index. 
also served as a member of the 1925 Commission for the Reform of Criminal Procedure. ${ }^{92}$

On January 4, 1927, a new Legislative Counsel assumed office upon appointment by incoming Governor C. C. Young. He was Fred B. Wood, now an Associate Justice of the District Court of Appeal in San Francisco, and his incumbency was destined to last from 1927 to 1950, thus providing for stability and a consistency of purpose in this field which had been sadly lacking. ${ }^{93}$ The 1927 legislature received the report of the special commission on criminal procedure, and enacted most of its recominendations into law. ${ }^{94}$ That session also enacted several measures destined to inaugurate the program for the revision and codification of California's statute law which has continued to the present time. One was the statute creating a special commission to codify the laws relating to the public schools, another was a statute providing for the creation of a Commission on Uniform State Laws, and the third was a resolution directing the Legislative Counsel to investigate the relative merits of codification, compilation, and revision of the statute law, as shown by the experience of other states and jurisdictions. ${ }^{95}$ Two other events took place at this time also which foreshadowed future practices: one, the first publication of an opinion by the Legislative Counsel as part of the proceedings of the legislature; and the other, an increased staffing of the office, well ahead of the 1929 session, in order to provide an advance bill-drafting service for the legislature..$^{90}$

$\mathbf{E}$

THE CALIFORNIA CODE COMMISSION (1929-1953)

The 1929 session opened under conditions which were extremely favorable front the point of view of statutory reform. Governor Young, who had previously indicated his interest in improving the operation of the legislative branch, commented in his message on the augmented services avail-

92 Supplement to the Index of the Laws of Catifornia (1921-1925) 136 pp. (1926) by Legislative Counsel Thomas M. Gannon.

${ }^{93}$ Judge Wood had served as a deputy under Legislative Counsels Will and Bush during the period from 1914 to 1922.

${ }^{94}$ Cf. 1927 Session, S.B. 361-418, which became Cal. Stats. 1927, c.407, 600-621, 628-634, $675-680,733-739,768$ and 854.

This was also the period which saw the creation of an integrated bar in California and the creation of a Judicial Council. See Cal. Stats. 1927, c.34 and CAL. Const. Art. VI, \& 1a (adopted Nov. 2, 1926).

05 Cal. Stats. 1927, cs.400, 498 and Res. c.43, p.2296.

${ }^{96}$ See Assem. Jour. 1801 (1927). Reliance on the Legislative Counsel's opimions in this fashion has increased throughout the years. Cf. California Legislative Materials, 4 Stan. L. REv. $367,371,376$ (1952).

See Governor Young's special message on advance drafting and printing of bills in SEN. JOUR. 14 (1928); ASSEM. JouR. 19 (1928). 
able to the legislature through the Legislative Counsel's office. ${ }^{97}$ During the interim period the Legislative Counsel, who was a member of the School Code Commission under the statute, acted in the capacity of executive secretary and his office did the drafting which resulted in the presèntation of the School Code to the 1929 legislature. ${ }^{98}$ The Legislative Counsel's report on revision of Califorma statute law was submitted to the legislature on the last day of the January portion of the session. The report, which was printed at length in the Assembly Journal, summarizes the procedures followed in other states and outlines several possibilities for California. ${ }^{99}$ On the same day two other steps were taken to implement the revision program. In the Assembly, Z. S. Leymel, who had authored the 1927 resolution calling for the Legislative Counsel's report, introduced a concurrent resolution creating a special joint committee which was to report back to the legislature on the problem following the constitutional recess. ${ }^{100}$ In the Senate, a bill was introduced by Senators Herbert C. Jones, George W. Rochester and H. C. Nelson which provided for the creation of a California Code Commission. ${ }^{101}$ The commission, which was to consist of nine mem-

${ }^{97}$ Supra note 96 . The Governor again stressed the need for advance preparation of bills, and his policy was incorporated into Chapter 67 of the Statutes of 1929 (now CAL. Gov. Code $\$ 9702)$. He also noted the work of the Legislative Counsel in connection with the proposed School Code and the general revision of California statutes. See AssEMr. Jour. 30 (1929). The Governor made a similar laudatory comment to the press concerning the operation of the office following adjournment for the constitutional recess (Sacramento Bee, Jan. 19, 1929).

98 Only $\$ 4,000$ was appropriated for this work by Chapter 400 of the Statutes of 1927 , and much of the cost of the clerical services was absorbed by the Legislative Counsel and the Superintendent of Public Instruction. No formal report of the commission was filed, but the School Code was enacted by Chapter 23 of the Statutes of 1929. This code, together with the 1929 amendments, was published separately from the 1929 statutes, thus following the 1872-73 precedent. (See supra notes 35 and 44.)

99 AsSEMr. Jour. 327-335 (1929). While the report does not recommend a particular solution, favorable mention is made of the organization of the statutes into several subject matter codes and it is noted that the proposed "school code" constitutes a step in that direction. Other evidences of the need for such an arrangement are found in the field of corporation law and laws relating to local districts. The report, while noting the requirements of CAL. Pox. CoDE $\$ \S 249$ and 250 (supra notes 60 and 82 ), does not find that the legislature has ever attempted the incorporation of all the general statutes into the four 1872 codes. See, also, Wood, Revision of the Statutes, 3 CALIF. ST. B.J. 51 (1928).

100 Cal. Stats. 1929, Res. c.9, p.2008. This resolution was introduced, passed in both houses and chaptered on January 18, the last day of the January part of the 1929 session. No report of the committee was found, but its chairman, Mr. Leymel, introduced Assembly Concurrent Resolution No. 35 on April 19, 1929 (Assenr. Jour. (1783). This resolution would have provided a joint interim committee on the same subject to report to the 1931 session of the Legislature. This concurrent resolution was never acted upon, possibly due to the creation of the Code Commission or to Mr. Leymel's resignation from the Assembly on April 22, 1929 to accept a local elective office in Fresno. See Assem. Jour. 1795 (1929). See, also, Statutory Revision in California, 3 CaLIF. ST. B.J. 168 (1929).

101 The bill was 1929 Session, S.B. 738, also introduced on January 18, and the authors included the chairman and two members of the Senate Judiciary Committee. It became Chapter 750 of the Statutes of 1929. 
bers appointed by the Governor, was directed to revise all the laws of the state and to report back by December 15, 1930, giving its recommendations to the 1931 legislature. All other state agencies were directed to render assistance to the commission, whose members were to receive expenses but no compensation. An amendment was adopted in the Senate on April 5, 1929, which made the Legislative Counsel secretary of the commission and directed him to pay all initial expenses of the commission out of the appropriation for the support of his office. Finally, the 1929 legislature created a "home rule commission," which was authorized to employ the Legislative Counsel as its secretary, and directed that it report back to the next session also. ${ }^{102}$

The Code Commission organized in January, 1930. Thomas C. Ridgway of Los Angeles, the second president of the State Bar of California, served as its chairman from that date until his death in $1938 .{ }^{103} \mathrm{He}$ was succeeded as chairman by another of the original appointees to the Commission, Gerald C. Hagar of Oakland, also a president of the State Bar, who served as chairman of the Commission until its work was complete in 1953. Unlike many of its predecessors, the Code Commission left a full and complete record of its activities which is available in many of our law libraries, and no attempt will be made to detail that record in this article. ${ }^{104} \mathrm{It}$ is desirable, however, to review some of the major problems confronted by the Commission during its lengthy consideration of California's statute law.

1.

\section{Classification of Statutes}

It had been the hope of the 1870-74 Code Commission, and its successors, that all of the statutory law could be incorporated ultimately into the "logical system" which the Field Codes contemplated. As has been indicated above, the various attempts at statutory revision which preceded the work of the 1929 Code Commission assumed that this was the direction in which statutory revision should proceed. ${ }^{105}$ This hope had been proved illusory, however, and the 1929 Code Commission made the following observation in its first report: ${ }^{106}$

102 Cal. Stats. 1929 , c.776.

${ }^{103}$ Cf. Thomas Caldwell Ridgway: A Memorial, 13 Caxr. Sx. B.J. No. 9, p.1 (1938); see also 4 CAr.F. ST. B.J. 163 (1930).

104 The Commission filed reports at each biennial session of the Legislature and filed a final report in September, 1953, which summarizes the entire project. These reports were printed, except for the two mimeographed reports submitted to the 1937 and 1939 sessions.

A complete summary of the Code Commission's work is given in Palmer and Selvin, Development of the Law in California, 1 West's Ans. CardForata Constitution 44-64 (1954).

105 Supra notes $45,48,56,61,62$.

106 Code Comantsston Report to the Legistature 7, 19 (1930). 
The present Codes were adopted in 1872. They did not, however, even at that time constitute a complete revision of the law. Since then no general revision has even been attempted. The situation today, therefore, is that there are four Codes and, in addition, about twenty-one thousand laws, contained in fifty volumes, and no one knows what laws are in force and what are not.

The California statutory law is in a deplorable condition. Familiarity with it tends to blind practitioners to its defects, but law writers and publishers unite in considering it the worst statutory law in the country.

The Commission concluded that the statutes could not be put into the four 1872 Codes and that, if they could be, hopeless confusion would result. Thus, the decision to abandon the "code system" as conceived by the earlier commissions and to create a new one was unavoidable. The Commission followed the lead of other states, such as New York, and adopted an alphabetical, subject-by-subject system of codes, which originally contemplated thirty-three titles including the original Civil Code, Code of Civil Procedure and Penal Code. ${ }^{107}$ The Commission considered the 1929 School Code to be a persuasive step in the direction of subject-matter codes for California. Pursuant to this decision, there was submitted to the 1931 legislature a draft of a Probate Code prepared by Perry Evans of San Francisco, a member of the Code Commission. By the time of its second report to the legislature, the Commission had settled upon twenty-five subjects which were to be incorporated into the new code system, a decision which was finally carried out by 1953 although some changes in allocation occurred in connection with particular codes during that period. ${ }^{108}$ In this classification only the Civil Code was thought by the Commission to be anomalous but, despite the severe criticism directed at that code throughout the years, it was felt that practical reasons dictated its retention. ${ }^{109}$

In recent years the Commission's plan of classification for Cahiforma's statutes has been carried out by the legislature gradually and without much debate although particular problems have been difficult to resolve. One by-product of the code system of classification has been the legislative practice of determining the jurisdiction of standing committees in accordance with the code structure. ${ }^{110}$ Because of this fact, primarily, a few of the

${ }^{107}$ Id. 16-18; 5 CAIIF. ST. B.J. 381, 286-391 (1930).

108 See Code Corantssion Report to the 1933 Legislature 21-26 (1933). Each of the succeeding reports contains a listing of the code subjects, as modified from time to time by the Commission. During this period two codes not proposed by the Commission were enacted into law: the Military Code (Cal. Stats. 1933, c.975) and the Banking Code (Cal. Stats. 1949, cs.755, 1276, 1277). Both were incorporated into subsequent codifications offered by the Commission.

109 Code Conarission Report to the 1931 Legistature 21 (1930). For criticism of the Civil Code, see works cited supra note 45; cf. Van Alstyne, The California Civil Code, 1 West's Ann. Crv. Code 1-43 (1954).

110 Cf. Standing Rules of the Senate, Rule 12 (SEN. Jour. 9-11, Mar. 1, 1954). 
Commission's decisions on allocation of statutes provoked substantial disputes which, upon occasion, delayed the codification of a particular area of statute law for a session or two. ${ }^{111}$ With the completion of the Code Commission's program in 1953, the responsibility for maintaining the code classification and for recommending the codification of each statute not allocated to a code as part of its enactment was assigned to the Legislative Counsel. In performing this assignment, needed codifications are reported to the legislature biennially so that a continuous system for keeping the code system in shape is available to the legislature. These reports are filed at the budget sessions of the legislature, $m$ even-numbered years, thus permitting the interim committees of the legislature to consider the issues involved prior to the conveming of the general sessions in odd-numbered years. ${ }^{112}$

\section{2.}

\section{Disposition of Uncodified Statutes}

The dilemma arising from the fact that prior commissions had not been able to make any effective disposition of the statutes which antedated their work was clearly appreciated by the inembers of the 1929 Code Commission. As they pointed out, no one could tell (in the absence of a court decision upon the specific point) what statutes, outside the codes, were in effect despite the existence of the codes. ${ }^{113}$ The Commission determined, therefore, that a page-by-page examination of each of the volumes of session laws was essential to a complete and effective job of codification. This examination produced an accurate, tabular check list of all California statutes, whether in the 1872 codes or not. The legislature authorized the pubbication of this Statutory Record in 1931 and, as continuously supplemented to date, it has furmished the basic foundation upon which California's codes have been built. ${ }^{114}$ The existence of the Statutory Record permitted the

111 For example, such a decision was whether to allocate the Unemployment Insurance Act to the Labor Code, the Welfare and Institutions Code or the Revenue and Taxation Code. See Code Comantssion Reports to the LegtsLature 9 (1947); 10, 11 (1949); 10 (1950); 11 (1952).

On a different basis, substantial opposition was expressed, which was later withdrawn, to including the law relating to both banks and building and loan associations within the framework of a single Financial Code. Cf. CODE COMMusston REPORTS TO THE LEGISLATURE 11 (1949), 9 (1950).

112 Report of Legistative Counset on Legistation Necessary to Manntain the Codes (1954); see ASSEMr. Jour. 18, 81 (1954).

113 Supra notes 36, 38, 39, 65, 105.

114 Legislative Counser, Statutory Record, 851 pp. (1933), authorized by Cal. Stats. 1931, c.584. This work was supplemented by Legistatrve Counsex, Statutory ReCORd SupPLEMENT, $539 \mathrm{pp}$. (1948), and by the cumulative table contamed in Cal. Stats. 1953, pp. 44054715. It will be supplemented in the session laws hereafter. See Ridgway, The Statutory Record: A History of the California Law, 8 CALIF. Sr. B.J. 190-191 (1933); and Code Comarassion Reports to the Legislature 14-15 (1930); 8, 17-18 (1933); 15-17 (1941); 24 (1949) ; CODE Comansston Final Report to the Legistature 9 (1953). 
Commission to prepare legislation which made specific disposition of the statutes affected by its proposed codes. This course of action had been contemplated, of course, by the earlier commissions but had proved impossible. The passage of years and the constant increase in legislative output at each session had aggravated the situation so that the problem in 1929 was one of overwhelming proportions.

The actions of the legislature based upon recommendations of the Code Commission are found in the session laws for each general legislative session from 1931 to 1953.115

As each Commission code was enacted, it was accompamed by an extended list of repeals so that the specter of implied repeals was eliminated. The session laws for each of the years when a Code Commission code or part thereof was enacted contains two cross-reference tables, one indicating the origin of each of the new code sections and the other indicating the disposition of the pre-existing statutes. ${ }^{116}$ Using the statute finders referred to above, it would not be difficult for a lawyer to determine what became of a particular portion of, for example, the Municipal Improvement Act of 1913. Without these aids that question might take some time to answer. ${ }^{117}$

As the bulk of uncodified and unrepealed statutes diminished in number, it became apparent to the Code Commission that an irreducible core of statutes would be left which could neither be repealed nor codified. For example, many old special acts affected vested rights and some recent legislation was very temporary in nature. Thus, the Commission regretfully concluded that it could not accomplish its assigned task of codifying or repealing all statutes in force, and it established certain categories of stat-

115 No one anticipated that the program would take that length of time because the magnitude of the task was not clearly understood. The Commission originally was directed to report to the 1931 session, and its existence was specifically extended in 1931 and in 1933. Finally, in 1935, the Commission's life was extended indefinitely and it was directed to report to each general session of the legislature. See Cal. Stats. 1929, c.750; Cal. Stats. 1931, c.929; Cal. Stats. 1933, c.645; Cal. Stats. 1935, c.698.

One factor contributing to the length of the project arose from the decision to have the staff work done in the office of the Legislative Counsel. Thus, it had to be worked into the schedule of that office. The Commission made no attempt to push its work to early completion, preferring to adopt a policy of regular reporting to each legislature.

116 Cf. Cal. Stats. 1953, pp. 4381-4390, giving the cross-references for the Unemployment Insurance Code. A complete list of the cross-reference tables for all Code Commission Codes is found in Code Comautsston Finar Report to the Legislature 17-19 (1953).

117 Answer: the statutory record shows that it was repealed by Cal. Stats. 1953, c.192 and the cross-reference table at Cal. Stats. 1953, pp. 4379-4380 shows where each of its sections and clauses were placed in the CaI. Streets ANd Hrghways Code.

See Hagar, Helpful Statute Finders Prepared by Code Commission Simplify Research, 16 CALIF. ST. B.J. 325-327 (1941).

The rules by which all of the codes were drafted, except for the three 1872 codes, are preserved in Report OF the Code Comantsston to the Legislature 25-37 (1949). 
utes as to which it would make no recommendations. ${ }^{118}$ It made sure, however, that virtually all of the live statute law of California had been incorporated into the code system and recommended that a final, page-by-page check be made of the session laws from 1849 to 1953 so that the 1955 legislature could repeal all uncodified statutes which might have escaped needed repeal during the course of the Commission's work. This assignment was undertaken by the Legislative Counsel and the report based thereon was submitted to the 1954 legislature for consideration in $1955 .{ }^{110}$ Action on this report in 1955 will eliminate all pre-existing legislation which might affect the codes in any way and will leave unrepealed only those categories of statute law which, in the opinion of the Code Commission, do not affect the live statutory law of California. ${ }^{120}$ Earlier code commissions had to make a listing of the "statutes in force" outside of the codes, because of the amount and substance of such legislation. Perhaps such a listing should be published now, indicating what statutes have never been specifically repealed even though such a hist would involve only matters of very limited interest, but this is a question of legislative policy upon wlich no prediction is possible at the present time. The California practitioner, despite this fact, has a very high degree of protection in relying upon the codes of California as a complete statement of our hive statutory law. ${ }^{121}$

\section{Publication of the Codes}

Early in its history the Code Commission decided that the experience of such other states as Wisconsin demonstrated the desirability of a statepublished system of codes. The Commission cited the experience of other states and concluded that, in this fashion, a good, inexpensive publication of the statute law could be guaranteed. This recommendation was made in

118 See Cal. Stats. 1929, c.750 § 2, for Commission's original mandate. For list of categories to be left unrepealed and uncodified, see CODE CONOMISSION REPORTS TO THE LEGISTATURE 17-22 (1949); 8-9 (1952); FinaI CODE REPORT to THE Legistature 7-9 (1953).

110 Report of Code Comanssion to the Legislature 12-13 (1952); Final Code ConsMIISSION REPORT TO THE LEGISLATURE 9 (1953); LEGISIATIVE COUNSEL, REPORT ON LEGISIATION NeCESSARy to MaINTAIN the Codes (1954), supra note 112.

120 Some of the unrepealed statute law, not yet reported to the legislature for action, involves the question whether legislative action is warranted where the sole reason for repeal is a matter of "clearing the record," e.g., the repeal of a statute whose effect has ceased by operation of its own provisions.

$121 C f$., for example, the problems involved in ascertaining the complete official text of federal statute law, as described in Price and Bitner, Effective Legar REsEARch 20-29, 70-76 (1953). California's favorable situation is dependent upon two main factors: (1) the continuous existence of a revision agency, and (2) the insistence that all revision be accomplished by specific legislative action, rather than by prima facie compilations of statute law. 
the Commission's first report and repeated thereafter. ${ }^{122}$ Chapter 46 of the Statutes of 1933 (now Government Code, Section 9762) directed the Legislative Counsel to prepare, and the State Printer to print, all new and revised codes enacted by the legislature, but this required merely the inclusion of the whole codification at a single place in the session laws of the particular year. ${ }^{123}$ Since then, the State Printer has periodically published an inexpensive edition of certain of the codes following each session of the legislature, but no attempt has been made to provide a state publication of the entire set of codes.

This pattern is consistent with Califorma's prior experience. The only state publication of the 1872 codes attempted was the one which followed immediately after the session which enacted them, and private publications were relied upon continuously thereafter. ${ }^{124}$ California has never conferred official status on any publication of its codes, except that the official publication of the session laws is authorized by Government Code, Sections 9763 through 9768. The Code Commission was understandably concerned lest its several codes remain buried in the session laws, but Deering's California Codes, published by the Bancroft, Whitney Company of San Francisco, have made available to the California lawyer a complete, annotated set of codes containing the entire body of statute law recommended by the Commission. A similar service was recently announced by West Publishing Conipany, of St. Paul, Minnesota.

The Code Commission was also anxious to insure a complete index to the California code system, and its reports recommend the state publication of such an index. ${ }^{125}$ This has not been attempted, and no comprehensive state-published index is available for the years since the Code Commission commenced its work. ${ }^{126}$ The private publications referred to above, however, contain such an index. There has also been available for this purpose, biennially since 1935, the Larmac Index to California Laws, published by the Recorder Printing and Publishing Company of San Francisco.

122 Reports of the Code Comartsston to tHe Legistature 9-10 (1930); 13-14 (1933); 18-19 (1935); 20 (1937, mimeographed); and FINAL REPORT 14 (1953). Legislation to implement the Commission's recommendation was offered several times in the legislature, but without success. Chapter 116 of Resolutions, Statutes of 1939, which purports to require statepublished codes, was apparently ineffective.

123 See, Cal. Stats. 1953, c.308, codifying the Unemployment Insurance Act. Upon occasion this practice has caused some confusion to attorneys simce the later chapters affecting such a code will not appear at length (see Cal. Stats. 1953, cs.309-313).

124 Parma and Armstrong, The Codes and Statutes of California: A Bibliography, 22 LAW IIB. J. 41,42 (1929).

125 Code Coantisston Reports to tHE LegtsLature 13 (1933); 18-19 (1935); 15 (1941); 12 (1952); and FINAT REPORT 14 (1953).

128 The various state indices, referred to in notes 78 and 89 supra were brought down to date in 1932 by the Legislative Counsel and the supplementary entries were published in LEGISIATIVE COUNSEx, StaTUTORY RECORD (1933). 
4.

\section{Limitations on the Commission's Work}

The experience of the various revision commissions which preceded the 1929 Code Commission highlighted hazards in addition to those already described. Not the least of them was the question whether it was possible to present an entire new code to the legislature without running onto the "simgle subject" and "complete re-enactment" shoals upon which the 1901 revisions had foundered. Not since Lewis v. Dunne had it been thought possible to present an entire revision as a single bill, at least where the 1872 codes were concerned, and the intervening revisions had been offered to the legislature in the form of innumerable separate acts. ${ }^{127}$ This problem was eased, of course, by the Code Commission's decision to repeal the Political Code in its entirety and to leave the Civil Code, Code of Civil Procedure and Penal Code substantially as they were. In addition, the Commission contemplated a subject-by-subject codification of the law, creating a high probability that the courts would use the subject matter selected by the Commission as the single subject contemplated by the Constitution. Also, no existing code was to be amended or revised, within the rule requiring re-enactment, but entirely new acts were to be presented. These grounds for distinguishing between the work of the 1929 Code Commission and the work of its predecessors proved convincing to the Supreme Court of California and Evans v. Superior Court ${ }^{128}$ replaced the Lewis case as the controlling court decision respecting statutory revision in California.

The Code Commission, however, was not content with the leeway created by the courts in dealing with the Probate Code. The potentially dangerous constitutional challenge was always present and reasonable minds could be expected to differ on how far it was possible to expand the limits of the single subject rule. Therefore, the Commission proposed an amendment to the Constitution which would have excepted the revisions proposed by it or any other revision agency from the restrictions of Article IV, Section 24 of the Constitution. ${ }^{129}$ This attempt was unsuccessful, however, despite repeated efforts by the Commission, and the entire codification of California statute law has been accomplished with the hazards of the single subject rule constantly in the background. Even the very substantial codi-

127 Supra notes 64-67. The legislative burden involved in considering many separate bills, session after session, constituted a major practical obstacle to revision, particularly with the all-inclusive program contemplated by the 1929 legislation creating the Code Commission.

128215 Cal. 58, 8 P.2d 467 (1932). On this problem, see Evans, Comments on the Probate Code of California, 19 CALIF. L. REv. 602 (1931), particularly the note at 602 concerning constitutionality.

129 Reports of the Code Commisston to the Legislature 12, 13, 29 (1933); 17, 24 (1935); FINAL REPORT 13 (1953). Cf. the similar constitutional amendment which was narrowly defeated at the polls in 1904, supra note 68. 
fication programs presented in 1951 and 1953, as part of the Commission's final clean-up of the statutes, were divided into separate subject areas which could be defended against attack on this ground. In the light of this policy, as well as the somewhat more flexible attitude of the courts, the Commission's program has apparently successfully avoided the hazards which proved so embarrassing to its predecessors.

Another minor difficulty which arose in the course of the codification program resulted from the fact that the 1872 codes were enacted by the legislature with section headings and marginal notations as part of the statute. Since section headings constituted part of the legislature's action in such cases, they were obviously available as an indication of legislative intent. ${ }^{130}$ While some section headings were included in the Vehicle Code and were enacted into law, the rest of the Commission's codifications were not enacted with such headings although private publishers of the codes invariably add them. This constitutes a real problem in statutory interpretation for the practising attorney since the editorial section headings certainly should not be taken as an indication of what the legislature intended. ${ }^{131}$ This difficulty was of concern to the Commission, particularly because it had eliminated section headings from its proposed codes. As a solution, the Commission recommended the enactment of legislation declaring that no headings, whether of sections, articles, chapters or whatever, were to be taken as indicating legislative intent. This recommendation was adopted by the legislature and added to each Code Commission codification, including the Vehicle Code. ${ }^{132}$

This brings us to a final, major problem inherited by the Code Commission from its predecessors. As has been apparent from the events recited above, none of the revision agencies which preceded the Code Commission had any hesitation in revising the substance of the statutes, as well as their

130 The rule is stated in Kahrs v. County of L.A., 28 Cal.App.2d 46, 49, 82 P.2d 29, 31 (1938). Also see $I n$ re Halcomb, 21 Cal.2d 126, 130, 130 P.2d 384, 386 (1942); and 23 CAI. Jur. $772-773$.

131 For a recent, unfortunate court decision which, in the opinion of the writer, cannot be taken as stating the proper rule, see Stokes v. County Clerk, 122 Cal.App.2d 229, 234, 264 P.2d 959, 963 (1954), where an editorial arrangement by Bancroft-Whitney Company, adopted long after the legislative action was complete, is used by the court in finding legislative intent.

132 Code Conmassion Report to the Legislature 12 (1943). See CaL. VeH. Code § 7; similar provisions in each of the Code Commission's codes. See also Note, 33 CaLIF. L. REv. 155-159 (1945).

Thus, only the Civil Code, the Code of Civil Procedure and the Penal Code contain section headings which can be used in ascertaining legislative intent. The publisher's practice in connection with these 1872 codes is to show the editorial headings in brackets; see DEERING's Penal Code xxiv (1949). However, attorneys are frequently deceived into using the nonbracketed headings appearing in the other codes. Cf. 14 OPs. CAL. ATTY. GEN. 220, 225 (1949) using a chapter heading as evidence of legislative intent despite the provisions of CAL. EDuc. CODE § 11, prohibiting just that. 
form. Most of them frankly conceded that they were undertaking to accomplish both tasks in a single proposal. It was clear in 1929, however, that the sheer bulk of the statutes which were to be revised precluded the Commission from offering substantive changes together with its changes in structure..$^{133}$ Early in its history, therefore, the Code Commission adopted the policy of offering to the legislature proposed codes in which it made no substantive change in the statutes to be revised. This policy was basic to the entire project and was faithfully followed throughout the Commission's existence, with a few notable exceptions.

The proposals for revising the constitutional and statutory provisions affecting the Commission's work, summarized above, were obviously attempts to secure substantive' change. In addition, Commissioner Evans' work on the Probate Code led the Commission to the conclusion that certain minor, non-controversial changes in substance could be accomplished as part of codification. The 1929 statute under which the Commission cominenced its work did not provide specifically for substantive recommendations, however, and an amendment for that purpose was asked by the Commission and given by the legislature in $1931 .{ }^{134}$ The problems involved in this authority to propose substantive changes soon received a testing in the arena of practical legislative procedure. The 1931 legislature provided for a legislative committee to revise the California Vehicle Act, and the Code Commission and its draftsmen assisted in the preparation of a Vehicle Code which was presented to the 1933 legislature. This code contained many important changes in the substance of the laws which were codified, though the policy changes were recommended by the legislative committee rather than by the Commission. The legislature of 1933 found this proposed code difficult to handle, and the Senate directed the Code Commission to report back to the Senate all of the substantive changes contained in the bill and to delete the substantive changes from the bill proposing the codification. ${ }^{185}$

133 This was made clear by Chairman Thomas Ridgway in one of his first public statements of Commission policy. Ridgway, Code Revision and Statutory Consolidation, 4 Carrr. ST. B.J. 171 (1930). This policy was continuously reaffirmed by the Commission and was heavily relied upon by the legislature in enacting the great volume of Code Commission bills session after session.

The courts have recognized and relied upon this policy also. Cf. cases cited in Code Coaranassion Finat Report to tae Legistature 8 (1953); So. Cal. Jockey Club v. Cal, etc, Racing Bd., 36 Cal.2d 167, 173, 233 P.2d 1, 5 (1950); Sobey v. Molony, 40 Cal.App.2d 381, 104 P.2d 868 (1940).

184 Reports of Code Commasston to the Legtslature 10 (1930); 10 (1933). See Evans, Comments on the Probate Code, 19 Carrr. L. Rev. 602, 603 (1931).

The authority to recommend changes in the substance of the statute law was conferred by Cal. Stats. 1931, c.929. As is indicated in the 1933 report cited above and in Commissioner Evans' article, the Commission was hopeful that non-controversial, quasi-substantive changes could be made as part of the process of codification.

185 Cal. Stats. 1931, Res. c.87, p.3149, provided for the revision by legislative committee. See Code Commisston Report to the Legistature 11 (1933). 
The Commission did this, during the 1933 session, but the code was not enacted. In preparation for the 1935 session the Commission drafted a codification of the vehicle laws without substantive change, and assisted interested groups in the preparation of separate measures by which the numerous changes in substance could be offered separately following the acceptance of the codification by the 1935 legislature. ${ }^{136}$ The Commission was not responsible, of course, for the changes in substance attempted in the proposed Vehicle Code of 1933, but its experience with that code undoubtedly laid the foundation for the policy which it adhered to in the codification program. Consistently thereafter, any policy changes which were offered by groups interested in particular codes were drafted in the form of separate measures, so-called "trailer bills," which were not the Commission's responsibility and were not protected by its prestige in the legislature. ${ }^{137}$ Upon other occasions, particularly in the early years of the Commission's history, some projects were undertaken in co-operation with other agencies which led to substantive revisions in particular fields of the law. This was particularly true in connection with that area of the law involving civil procedure and evidence. ${ }^{138}$ The Code Commission, however, finally accepted the formal revision of our statutes as its sole function and realized that the accomplishment of this task constituted a tremendous assignment. As its work reached completion, the Commission tried to lay the foundation for continumg statutory revision and was largely responsible for the 1953 legislation turning over to a successor agency, the California Law Revision Commission, the responsibility for revising the statutes of California in matters of substance, ${ }^{139}$

The bills involved were 1933 Session, A.B. 662-672 and 674. See SEN. Jour. 2986 (May 12, 1933), for resolution referring bills to the Code Commission. The Commission reported back to the Senate on July 1, 1933, SEN. Jour. 3266-3267 (July 19, 1933), but no further action was taken in the Senate.

136 Code Conmission Report to the LEGISIATURE 10 (1935). This report also announced the Commission's "definite policy not to make substantive changes" as part of codification (id. at 8).

137 Neither are they subject to the rule of interpretation applied to the Commission's bills, i.e., that no change in substance is intended. Cf. DEERInG's UNemployment Insurance Code ANNotated $\S 302$, as added by Cal. Stats. 1953, c.308 and amended by Cal. Stats. 1953, c.1764. 138 See Code Conantassion's Finat Report to the Ligistature 12 (1953).

139 The groundwork for creating the new California Law Revision Commission was laid througli the Code Commission's 1949, 1951 and 1953 reports. See, also, Crotty, New Legislation-A Constructive Suggestion, 28 CALIF. ST. B.J. 42 (1953); 27 id. at 178 (1952); 28 id. at

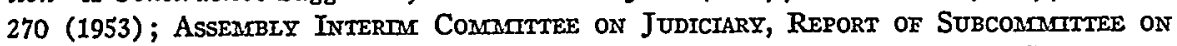
Untrorar Acts and Code Contrssion, 7 pp. (1953); Senate Interma Judictary ComTuttiee, SECOND PROGRESS REPORT 129-134 (1953).

CAL. Gov. CODE $\$ \S 10300-10340$, provide for the new commission and specify its duties. The same act abolished the Code Commission and turned over its responsibilities in the field of formal revision to the Legislative Counsel (see CaL. Gov. Code § 10242). 
F

\section{STATUTORY REVISION FOR THE FUTURE}

The dichotomy between revision in form and revision in substance which has been found necessary throughout the history of the Code Commission will be continued into the future. The new California Law Revision Commission has been organized pursuant to the 1953 legislation and has selected the Stanford University School of Law as the site for its research activities, much after the pattern set by its prototype, the New York Law Revision Commission. In addition to its general responsibilities, two specific requests have been made of the Commission by the legislature, and it will file its first report at the 1955 session of the legislature. ${ }^{140}$ In the field of substantive revision of the law, many agencies other than the new Law Revision Commission will be at work throughout the coming years, as they have been in the past, but the new Commission can be expected to play a substantial role in the development of our statutes. Insofar as codification without substantive change is required in the future, the Legislative Counsel will undertake to report it to the legislature and its committees.

If any rule is to be deduced from California's one hundred years of statutory revision, it is that change is the condition of our existence and that a continuous modification of our statutes must be expected. The 1929 Code Commission has, with great difficulty, created the master plan upon which this future development of our statutes can be based and its history, as well as that of its predecessors, has taught us many a hard lesson. It is to be hoped that some of those lessons have been preserved in this article in such a way that the inevitable revisions of the future will be easier than those of the past.

140 Stanton, The California Law Revision Commission, 29 Car.r. Sr. B.J. 196-200 (1954). The officers of the Commission are: Thomas E. Stanton, Jr. of San Francisco, Chairman; John D. Babbage of Riverside, Vice-Chairman; and Professor John McDonough, Jr. of Stanford, Executive Secretary. Cal. Stats. 1953, c.1682, requests the Commission to revise the Education Code and Cal. Stats. 1954 (1st Extra. Session), Res. c.22, requests a revision of the summary probate provisions of the Probate Code. 